\title{
Analisis Kinerja Reksadana Saham Syariah Di Pasar Modal Indonesia Menggunakan Metode Sharpe, Treynor, Dan Jensen Periode 2017-2018
}

\author{
Ahmad Karim Abdul Hamid ${ }^{1}$, Iwan Fahri Cahyadi ${ }^{2}$ \\ 1,2Institut Agama Islam Negeri Kudus, Kudus \\ $\square^{1}$ akahamid24@gmail.ac.id, $\rrbracket^{2}$ iwanfahri@iainkudus.ac.id
}

\begin{abstract}
This research aims to find out the performance of sharia stock mutual funds in the Indonesian Capital Market based on sharpe, treynor and jensen methods and to find out the comparison of the performance of sharia stock mutual funds with benchmark performance in the research period of 2017-2018. This type of research is evaluative research with a quantitative approach. The population in this study includes all sharia mutual funds registered and still active in the Financial Services Authority (OJK) until December 2018. Sampling techniques used purposive sampling techniques and obtained 23 sharia stock mutual funds as a research sample. Data analysis techniques are descriptively analyzed, the data obtained is collected and then processed with the appropriate formulas on the operational definition of measurement and research variables. Data analysis techniques are descriptively analyzed, the data obtained is collected and then processed with the appropriate formulas on the operational definition of measurement and research variables. To make data processing easier using microsoft excel programs. Based on the analysis of islamic stock fund performance data according to sharpe method in 2017 there are 7 sharia stock mutual funds that show positive performance, and in 2018 there were 3 sharia stock mutual funds showing positive performance. Meanwhile, according to treynor method in 2017 there were 7 sharia stock mutual funds that showed positive performance, and in 2018 there were 3 sharia stock mutual funds that showed positive performance. Meanwhile, according to jensen method in 2017 there are 6 sharia stock mutual funds that showed positive performance, and in 2018 there were 5 sharia stock mutual funds that showed positive performance. Based on the results of the comparison of the performance of sharia stock mutual funds with benchmarks in the period 2017 according to sharpe method there are 5 sharia stock mutual funds that have outperform performance, and in the period 2018 there are 3 sharia stock mutual funds that have outperform performance. Meanwhile, according to treynor method in 2017 there are 1 sharia stock mutual fund that has outperform performance, and in 2018 there are 20 sharia stock mutual funds that have outperform performance. While according to jensen method in 2017 there are no sharia stock mutual funds that have outperform performance, and in the period 2018 there are 23 sharia stock mutual funds that have outperform performance. And there are 2 sharia stock mutual funds that consistently perform best against market performance during the research period, namely Sucorinvest Sharia Equity Fund sharia stock mutual fund and Sharia Pacific Saham Syariah stock fund.
\end{abstract}

Keywords : Syariah Equity Fund, Sharpe, Treynor and Jensen Fund, Jakarta Islamic Index 


\section{LATAR BELAKANG}

Perkembangan pasar modal dewasa ini mampu menarik perhatian para pelaku investasi. Kemudahan akses dan keuntungan yang ditawarkan oleh pasar modal menjadi daya tarik kepada para investor. Reksadana merupakan salah satu bentuk investasi yang memberikan kemudahan yaitu dengan menghimpun dana dari calon investor untuk diinvestasikan di pasar modal oleh manajer investasi.

Berdasarkan Undang-Undang Pasar Modal tahun 1995 No. 8 pasal 1 ayat 27 mendefinisikan reksadana sebagai wadah yang dipergunakan untuk menghimpun dana dari masyarakat pemodal untuk selanjutnya diinvestasikan dalam portofolio efek oleh manajer investasi. Berinvestasi di reksadana akan terkumpul dana yang cukup besar. Besarnya dana yang ada di reksadana, maka akses untuk melakukan diversifikasi investasi semakin besar begitu juga dengan resiko yang di hadapi akan semakin kecil (Hadi, 2013).

Reksadana di Indonesia mulai muncul sekitar tahun 1970-an, yaitu sejak PT. Danareksa didirikan pada tahun 1977 bersamaan dibuka kembali di bidang Bursa Efek Jakarta (Hadi, 2015a). Kemudian hadir reksadana syariah sejak tahun 1997 di Indonesia melengkapi keragaman reksadana konvensional yang telah ada sebelumnya. Perbedaan paling mendasar antara reksadana konvensional dengan reksadana syariah adalah terletak pada proses screening dalam proses manajemen portofolio dan proses cleansing yang dilakukan dengan cara membersihkan pendapatan yang dianggap diperoleh dari kegiatan haram dan membersihkannya dengan cara charity (Inggi, 2000).

Fatwa Dewan Syariah Nasional (DSN) MUI Nomor 20/DSN MUI/IV/2001 mendefinisikan reksadana syariah sebagai reksadana yang beroperasi berdasarkan ketentuan dan prinsip syariah Islam, baik dalam bentuk akad antara pemodal sebagai pemilik harta (shahib al-mal/rabb al-mal) dengan manajer investasi sebagai wakil shahib al-mal dengan pengguna investasi (Fatwa SDN-MUI, 2001).

Berdasarkan ketentuan peraturan Otoritas Jasa Keuangan Nomor 19/POJK.04/2015 tentang Penerbitan dan Persyaratan Reksadana Syariah, terdapat beberapa jenis reksadana syariah, yaitu reksadana pendapatan tetap, reksadana campuran, reksadana pasar uang, reksadana saham, reksadana terproteksi, reksadana indeks, reksadana berbasis efek syariah luar negeri, reksadana berbasis sukuk, reksadana berbentuk kontrak investasi kolektif yang unit penyertaannya diperdagangkan di bursa dan reksadana berbentuk kontrak investasi kolektif penyertaan terbatas (POJK, 2015). Calon investor dapat memilih instrumen reksadana syariah yang akan dialokasikan dananya sesuai dengan tingkat risiko dan return yang diinginkan. Berdasarkan sepuluh jenis reksadana syariah yang terdaftar di Otoritas Jasa Keuangan (OJK), reksadana saham syariah merupakan jenis reksadana syariah yang paling banyak diminati oleh investor.

Reksadana dapat dikatakan sebagai wadah bagi para pemodal untuk dapat menginvestasikan sebagian aset yang dimiliki dengan dana yang terbatas tanpa harus mengorbankan waktu untuk mengawasi dan mengelola perkembangan dari aset yang dikorbankan karena sudah dikelola oleh profesional yang sering disebut dengan manajer investasi. Manajer investasi yang bertindak sebagai perusahaan efek adalah yang telah memperoleh izin operasional dari OJK dan terlebih dahulu berkonsultasi dengan dewan pengawas syariah. Banyak investor baik individual maupun institusional mempercayakan pengelolaan investasinya kepada manajer investasi. Manajer investasi melakukan investasi pada berbagai instrumen tersebut mempunyai 
besaran yang berbeda-beda sesuai dengan perhitungan manajer investasi untuk mencapai tingkat pengembalian yang diharapkan. Dengan mempercayakan pengelolaan dana tersebut investor berharap akan mendapatkan pengembalian yang wajar dengan menanggung risiko tertentu. Dengan demikian manajer investasi mempunyai peranan yang menentukan dalam keberhasilan investasi. Untuk mengetahui reksadana yang optimal harus dilakukan pengukuran kinerja reksadana.

Kinerja reksadana adalah kemampuan dari reksadana untuk memberikan return tertentu sesuai dengan tingkat risiko tertentu. Tingkat risiko adalah kemungkinan return aktual yang diharapkan karena faktor-faktor yang memengaruhinya, semakin besar return dan makin kecil risiko yang dihasilkan maka semakin tinggi rasionya, semakin baik kinerja reksadana tersebut (Pratomo, 2009). Jadi investor akan memperoleh tingkat return yang optimal dengan tingkat risiko yang sebanding apabila kinerja reksadana baik.

Investor dalam mengukur kinerja reksadana ada beberapa faktor yang perlu diperhatikan, seperti tingkat risiko, periode waktu, penggunaan patok duga (benchmark) dan tujuan investasi. Tandelilin menjelaskan bahwa dalam mengevaluasi kinerja reksadana harus memperhatikan tingkat return reksadana yang diperoleh harus sudah cukup memadai untuk menutup risiko yang harus ditanggung (Tendelilin, 2010). Terdapat dua pengukuran kinerja yaitu melalui return reksadana itu sendiri dan model risk adjusted return. Adapun metode untuk melakukan penilaian kinerja dengan menggunakan return reksadana itu sendiri adalah raw return. Sedangkan risk adjusted return adalah perhitungan return yang disesuaikan dengan risiko yang harus ditanggung, adapun metodenya antara lain: treynor ratio, sharpe ratio, jensen alpha, roy safety first ratio, sortino ratio, msr, fpi, dan information ratio (Hartono, 2010a). Dalam penelitian ini menggunakan model risk adjusted return dengan metode pengukuran untuk menilai kinerja reksadana, yaitu treynor ratio, sharpe ratio, dan jensen alpha.

Metode sharpe dikembangkan oleh William F. Sharpe pada tahun 1966. Hartono menyebutkan bahwa kinerja portofolio yang diukur dengan metode sharpe dilakukan dengan membagi return lebih dengan variabilitas return portofolio, maka dari itu pengukur ini disebut juga dengan metode reward to variability (RVAR). Variabilitas pada metode ini diukur dengan deviasi standar dari return portofolio pada periode tertentu. Metode reward to marketrisk pada dasarnya merupakan modifikasian dari metode treynor. Modifikasi ini bertujuan agar hasilnya dapat dibandingkan dengan metode sharpe dengan cara mengubah risiko sistematik dalam skala desimal menjadi skala persentase. Hartono menyebutkan bahwa pengukuran jensen alpha diperkenalkan oleh Michael C. Jensen pada tahun 1968. Pengukuran ini dikembangkan dari capital asset pricing model (CAPM). Jensen alpha mengukur kinerja portofolio dengan menyelisihkan antara return rata-rata portofolio dengan rata-rata risiko pasar (Hartono, 2014).

Penelitian yang dilakukan oleh Soesanty pada tahun 2013 berdasarkan analisis yang dilakukan terhadap 8 reksadana saham syariah diperoleh 5 reksadana saham syariah yang memberikan kinerja positif berdasarkan metode sharpe, dan 6 reksadana saham syariah yang memberikan kinerja positif berdasarkan metode treynor. Reksadana yang memberikan kinerja negatif selama periode pengukuran berdasarkan metode sharpe 3 reksadana, dan treynor 2 reksadana.

Penelitian lain yang dilakukan oleh Solkhan pada tahun 2015 berdasarkan analisis yang dilakukan terhadap 6 reksadana saham syariah diperoleh 4 reksadana saham yang memberikan kinerja positif berdasarkan metode sharpe. Sedangkan 
menggunakan metode treynor diperoleh 4 reksadana saham yang memberikan kinerja positif. Reksadana yang memberikan kinerja negatif selama periode pengukuran berdasarkan metode sharpe 2 reksadana saham dan berdasarkan metode treynor 2 reksadana saham. Dan reksadana saham syariah yang memiliki kinerja konsisten terbaik selama periode penelitian yaitu reksadana saham syariah Manulife Syariah Sektoral Amanah.

Penelitian lain yang dilakukan oleh Wahyuni pada tahun 2016 Menurut metode sharpe dan treynor pada periode Maret 2013-Februari 2014 tidak terdapat reksadana saham syariah yang berkinerja positif sedangkan pada periode Maret 2014-Februari 201511 reksadana saham syariah berkinerja positif dan pada periode Maret 2015-Februari 2016 tidak terdapat reksadana saham syariah yang berkinerja positif. Menurut metode jensen pada periode Maret 2013-Februari 2014 terdapat 1 reksadana saham syariah berkinerja positif sedangkan pada periode Maret 2014Februari 2015 terdapat 11 reksadana saham syariah berkinerja positif dan pada periode Maret 2015-Februari 2016 tidak terdapat reksadana saham syariah yang berkinerja positif. Menurut metode $M^{2}$ pada periode Maret 2013-Februari 2014 terdapat 2 reksadana saham syariah berkinerja positif sedangkan pada periode Maret 2014-Februari 2015 terdapat 11 reksadana saham syariah berkinerja positif dan pada periode Maret 2015-Februari 2016 tidak terdapat reksadana saham syariah yang berkinerja positif. Dan terdapat 1 reksadana saham syariah yang outperform secara konsisten selama periode penelitian yaitu reksadana saham syariah SAM Sharia Equity Fund.

Penelitian lain yang dilakukan oleh Handayani pada tahun 2018 berdasarkan hasil analisis data menggunakan metode sharpe dan treynor menunjukan hasil yang sama, pada tahun 2015 tidak terdapat reksadana saham syariah yang berkinerja positif. Pada tahun 2016 terdapat 18 reksadana saham syariah yang berkinerja positif dan pada tahun 2017 terdapat 7 reksadana saham syariah yang berkinerja positif. Reksadana saham syariah yang konsisten memiliki kinerja positif dan outperform selama tahun 2016 dan 2017 terhadap kinerja benchmark pada semua metode yaitu reksadana saham syariah Sucorinvest Sharia Equity Fund.

Beberapa hasil penelitian sebelumnya diatas menunjukkan bahwa terlihat adanya inkonsistensi hasil penelitian atau perbedaan pada hasil penelitian, karena sedikitnya jumlah produk reksadana saham syariah yang digunakan sebagai sampel dan juga metode yang digunakan peneliti masih jarang yang menggunakan metode Jensen. Serta dari waktu ke waktu konstituen dari perusahaan reksadana saham syariah selalu mengalami perubahan tiap tahunnya, inilah yang memotivasi penulis untuk meneliti kembali mengenai reksadana saham syariah. Melalui penelitian ini diharapkan dapat menjadi bahan masukan dan pertimbangan untuk mengetahui kondisi kinerja reksadana saham syariah sehingga investor mengetahui reksadana saham syariah mana saja yang memiliki kinerja konsisten. Penelitian ini adalah "Analisis Kinerja Reksadana Saham Syariah di Pasar Modal Indonesia Menggunakan Metode Sharpe, Treynor, dan Jensen Periode 2017-2018.

\section{TEORI DAN METODE}

\subsection{Teori}

\subsubsection{Pasar Modal}

Pasar modal merupakan indikator perekonomian suatu negara. Pada dasarnya, pasar modal merupakan pasar atau sarana bagi investor dalam berbagai 
transaksi instrumen keuangan atau surat-surat berharga yang bisa diperjualbelikan dalam bentuk utang atau modal. Oleh karena itu pembahasan pasar modal dimulai dari definisinya, instrumennya, dan analisis ekonomi.

Pasar modal adalah pertemuan antara pihak yang memiliki kelebihan dana dengan pihak yang membutuhkan dana dengan cara memperjualbelikan sekuritas. Pasar modal juga diartikan sebagai pasar untuk memperjualbelikan sekuritas yang umumnya memiliki umur lebih dari satu tahun, seperti saham dan obligasi. Sedangkan tempat dimana terjadinya jual beli sekuritas disebut dengan bursa efek. Maka dari itu, bursa efek merupakan arti dari pasar modal secara fisik (Tendelilin, 2001)

Pasar modal sebagai pasar untuk berbagai instrumen keuangan (sekuritas) jangka panjang yang dapat diperjualbelikan, baik dalam bentuk hutang ataupun modal sendiri, baik yang diterbitkan oleh pemerintah, public authorities, maupun perusahaan swasta (Husnan, 2001). Pasar modal memfasilitasi perusahaan untuk mencukupi kebutuhan dana jangka panjang dengan menjual surat berharga berupa surat pengakuan utang, surat berharga komersial, saham, obligasi, tanda bukti utang, unit penyertaan kontrak investasi kolektif, kontrak berjangka atas efek, dan setiap derivatif dari efek.

Perusahaan yang membutuhkan dana dapat menjual surat berharganya ke pasar modal. Surat berharga yang baru dikeluarkan oleh perusahaan pada saat Initial Public Offering (IPO) dijual di pasar primer. Surat berharga yang sudah beredar, kemudian diperdagangkan di pasar sekunder. Pasar ketiga dijalankan oleh broker pada saat pasar sekunder (kedua) tutup. Pasar keempat dilakukan diantara institusi berkapasitas besar untuk menghindari komisi broker. Pasar keempat umumnya menggunakan jaringan komunikasi untuk memperdagangkan saham dalam jumlah blok yang besar, misalnya Instinet yang dimiliki oleh Reuter yang menangani lebih dari satu miliar lembar saham tiap tahunnya (Hartono, 2010b).

\subsubsection{Investasi dalam Perspektif Syariah}

Islam mendorong setiap manusia untuk bekerja dan meraih sebanyakbanyaknya materi. Islam memperbolehkan setiap manusia mengusahakan harta sebanyak ia mampu, mengembangkan, memanfaatkannya sepanjang tidak melanggar ketentuan agama. Dalam Islam investasi merupakan kegiatan muamalah yang sangat dianjurkan, karena dengan berinvestasi, harta yang dimiliki menjadi produktif dan juga mendatangkan manfaat bagi orang lain. Al-Qur'an dengan tegas melarang aktivitas penimbunan terhadap harta yang dimiliki. Dalam sebuah hadits, Nabi Muhammad SAW bersabda: "Ketahuilah, barang siapa yang memelihara anak yatim, sedangkan anak yatim tersebut memiliki harta, maka hendaklah ia menginvestasikannya (membisniskannya) janganlah ia membiarkan harta itu idle, sehinga harta itu terus berkurang lantaran zakat. (Yuliana, 2010)

Investasi merupakan salah satu ajaran dari konsep islam. Hal tersebut dapat dibuktikan bahwa konsep investasi selain sebagai pengetahuan juga bernuansa spiritual karena menggunakan prinsip syariah, sekaligus merupakan hakikat dari sebuah ilmu dan amal, oleh karenanya investasi sangat dianjurkan bagi setiap muslim. Hal tersebut di jelaskan dalam Quran surat Al-hasyr ayat 18 sebagai berikut: "Hai orang-orang yang beriman, bertaqwalah kepada Allah dan hendaklah setiap diri memerhatikan apa yang telah diperbuatnya untuk hari esok (akhirat), dan bertaqwalah kepada Allah sesungguhnya Allah Maha Mengetahui apa yang kamu kerjakan" (QS. Al-Hasyr: 18). 
Dalam Al-Quran surat Lukman ayat 34 secara tegas Allah menyatakan bahwa tiada seorang pun di alam semesta ini yang dapat mengetahui apa yang akan diperbuat, diusahakan serta kejadian apa yang akan terjadi pada hari esok. Sehingga dengan ajaran tersebut manusia diperintahkan untuk melakukan investasi sebagai bekal dunia akhirat: "Sesungguhnya Allah, hanya pada sisi-Nya sajalah pengetahuan tentang hari Kiamat; dan Dia-lah yang menurunkan hujan, dan mengetahui apa yang ada dalam rahim. dan tiada seorangpun yang dapat mengetahui (dengan pasti) apa yang akan diusahakannya besok. dan tiada seorangpun yang dapat mengetahui di bumi mana Dia akan mati. Sesungguhnya Allah Maha mengetahui lagi Maha Mengenal" (QS. Al-Luqman: 34).

Dalam investasi Allah dan Rosul-Nya memberikan petunjuk (dalil) dan ramburambu pokok yang dapat diikuti oleh setiap umat muslim yang beriman. Di antara rambu-rambu tersebut adalah sebagai berikut:

a) Terbebas dari unsur riba

Riba secara etimologi berarti tumbuh dan bertambah. Riba dilarang karena termasuk dalam kategori mengambil atau memperoleh harta dengan cara tidak benar.

b) Terhindar dari unsur gharar

Gharar secara etimologi bermakna kekhawatiran atau resiko, dan gharar berarti juga menghadapi suatu kecelakaan, kerugian, dan kebinasaan.

c) Terhindar dari unsur judi (maysir)

Maysir merupakan bentuk objek yang diartikan sebagai tempat untuk memudahkan sesuatu. Dikatakan memudahkan sesuatu karena seseorang yang seharusnya menempuh jalan yang susah payah akan tetapi mencari jalan pintas dengan harapan dapat mencapai apa yang dikehendaki, walupun jalan pintas tersebut bertentangan dengan nilai serta aturan syariah.

d) Terhindar dari unsur haram

Investasi yang dilakukan oleh investor muslim diharuskan terhindar dari unsur haram. Sesuatu yang haram merupakan segala sesuatu yang dilarang Allah SWT dan Rasul-Nya.

e) Terhindar dari unsur syubhat

Kata syubhat berarti mirip, serupa, semisal, dan bercampur. Dalam terminologi syariah syubhat berarti sebagai sesuatu perkara yang tercampur (antara halal dan haram), akan tetapi tidak diketahui secara pasti apakah ia sesuatu yang halal atau haram, dan apakah ia hak ataukah batil. Seorang investor muslim disarankan menjauhi aktivitas investasi yang beraroma syubhat, karena jika hal tersebut tetap dilakukan maka pada hakikatnya telah terjerumus pada suatu yang haram.

\subsubsection{Nilai Aktiva Bersih}

Nilai aktiva bersih (NAB) atau disebut juga net asset value (NAV) merupakan nilai pasar wajar (fair market value) suatu efek dan kekayaan lain dari reksadana dikurangi dengan kewajiban. NAB merupakan salah satu tolok ukur dalam memantau hasil dari suatu reksadana. Nilai aktiva bersih per unit penyertaan adalah harga wajar dari portofolio suatu reksadana setelah dikurangi biaya operasional kemudian dibagi jumlah saham/unit penyertaan yang telah beredar (dimiliki investor) pada saat tersebut (Iman, 2008). Adapun rumus NAB adalah : (Jumlah Asset- Total Kewajiban)/Jumlah Unit Penyertaan.

Naik turunnya NAB/unit reksadana dipengaruhi oleh nilai pasar dari masingmasing efek yang dimiliki oleh reksadana tersebut. NAB reksadana dihitung dengan menjumlahkan seluruh nilai masing-masing efek yang dimilikinya, berdasarkan harga 
pasar penutupan efek yang bersangkutan, kemudian mengurangi dengan kewajibankewajiban reksadana seperti biaya Manajer Investasi, biaya Bank Kustodian dan biaya lainnya. Bank Kustodian berkewajiban menghitung NAB reksadana, yang kemudian dikirimkan ke surat kabar harian tertentu.

Untuk mengetahui kineja reksadana atau posisi NAB dari masing masing reksadana dapat dilihat melalui laporan resmi berbentuk surat dari Manajer Investasi kepada nasabah reksadana, atau dengan melihat pengumuman NAB reksadana pada beberapa surat kabar, seperti Harian Bisnis Indonesia atau Harian Investor Indonesia (Rahardjo, 2004).

\subsubsection{Benchmark}

Dalam menentukan baik atau tidaknya kinerja reksadana, diperlukan suatu pembanding. Dengan adanya pembanding, kita dapat mengetahui tinggi rendahnya return dan risiko reksadana. Reksadana dikatakan memberikan return tinggi apabila returnnya di atas return pembanding. Sebaliknya reksadana dikatakan berisiko rendah apabila risikonya lebih kecil dibandingkan risiko pembanding. Instrumen yang dianggap sebagai pembanding itulah disebut dengan benchmark (Rudiyanto, 2019)

Benchmark pada reksadana dimaksudkan untuk mengetahui apakah reksadana yang dikelola manajer investasi dapat "mengalahkan" pasar (outperform) atau justru kalah dari pasar (underperform). Indeks pasar digunakan sebagai pembanding (benchmark) pada reksadana.

Penentuan pembanding reksadana sangat penting, karena merupakan sebuah data yang menyatakan bahwa sebuah reksadana tersebut lebih baik atau tidak. Peran benchmark dalam evaluasi kinerja reksadana adalah untuk membandingkan tingkat pengembalian yang dapat diperoleh dari alternative investasi lain yang seimbang. Dengan demikian, benchmark dalam evaluasi kinerja reksadana harus benar-benar dapat mewakili kebijakan investasi dari reksadana, serta sesuai dengan tujuan investasi investor.

\subsubsection{Reksadana}

\section{a. Pengertian Reksadana}

Reksadana berasal dari kata "reksa" yang berarti jaga atau pelihara dan kata "dana" berarti uang. Sehingga reksadana dapat diartikan sebagai kumpulan uang yang dipelihara. Pada umumnya reksadana diartikan sebagai wadah yang dipergunakan untuk menghimpun dana dari masyarakat pemodal untuk selanjutnya diinvestasikan dalam portofolio efek (Susanto, 2008).

Menurut UU Pasar Modal No. 8 Tahun 1995 Reksadana merupakan wadah yang digunakan untuk menghimpun dana dari masyarakat pemodal untuk selanjutnya diinvestasikan dalam portofolio efek oleh manajer investasi yang telah mendapat izin dari Bapepam (Hadi, 2015c). Portofolio investasi dari reksadana dapat terdiri atas berbagai macam instrumen surat berharga seperti saham, obligasi, instrumen pasar uang, atau campuran dari instrumen-instrumen diatas.

Dalam Kamus Keuangan, Reksadana didefinisikan sebagai portofolio aset keuangan yang terdiversifikasi, dicatatkan sebagai perusahaan investasi yang terbuka, yang menjual saham kepada masyarakat dengan harga penawaran dan penarikanya pada nilai aktiva bersihnya.

Reksadana adalah suatu kumpulan dana dari masyarakat atau pemodal (investor) yang kemudian dikelola oleh sebuah institusi bernama Manajer Investasi untuk di 
investasikan pada berbagai jenis portofolio investasi efek atau produk keuangan lainnya (Situmorang, 2010)

Dari uraian diatas secara jelas disebutkan bahwa reksadana tersebut mempunyai beberapa karakteristik yaitu: pertama, kumpulan dana dan pemilik, dimana pemilik reksadana adalah berbagai pihak yang menginvestasikan atau memasukkan dananya ke reksadana dengan berbagai variasi. Kedua, diinvestasikan kepada efek yang dikenal dengan instrumen investasi. Ketiga, reksadana tersebut dikelola oleh Manajer Investasi. Keempat, reksadana merupakan instrumen investasi jangka menengah dan panjang. Kelima, reksadana merupakan produk investasi yang berisiko (Manurung, 2008).

\section{b. Reksadana Syariah}

Fatwa Dewan Syariah Nasional (DSN) MUI Nomor 20/DSN MUI/IV/2001 mendefinisikan reksadana syariah sebagai reksadana yang beroperasi berdasarkan ketentuan dan prinsip syariah Islam, baik dalam bentuk akad antara pemodal sebagai pemilik harta (shahib al-mal/rabb al-mal) dengan manajer investasi sebagai wakil shahib al-mal dengan pengguna investasi (Fatwa DSN-MUI, 2001).

Reksadana Syariah merupakan reksadana yang mengalokasikan seluruh dana/ portofolio ke dalam instrumen syariah, seperti saham yang tergabung dalam Jakarta Islamic Index (JII), obligasi syariah, dan berbagai instrumen keuangan syariah lainnya (Sutedi, 2011).

Reksadana syariah diperkenalkan pertama kali pada tahun 1995 oleh National Commercial Bank di Saudi Arabia dengan nama Global Trade Equity dengan kapitaliasasi sebesar U\$ 150 juta. Adapun di Indonesia diperkenalkan pertama kali pada tahun 1998 oleh PT Danareksa Investment Management, dimana pada saat itu PT Danareksa ini mengeluarkan produk reksadana berdasarkan prinsip Islam berjenisreksadana campuran yang dinamakan "Danareksa Islam Berimbang" (Huda dan Heykal, 2010)

Dalam penyusunan portofolio investasinya, reksadana syariah hanya dapat menempatkan dananya kedalam instrumen-instrumen investasi yang terbebas dari riba dan praktik-praktik tidak halal menurut syariah. Pada instrumen pasar modal reksadana syariah hanya menempatkan dananaya pada emiten atau perusahaan atau pihak-pihak penerbit instrumen investasi yang tidak melakukan usaha-usaha yang bertentangan dengan prinsip kehalalan syariah seperti riba, perjudian, pornografi, minuman haram, babi, dan hiburan yang bertentangan dengan prinsip syariah.

\section{c. Mekanisme Reksadana Syariah}

Dalam melakukan kegiatan investasi reksadana syariah dapat melakukan apa saja sepanjang tidak bertentangan dengan syariah dan yang telah ditentukan oleh Dewan Pengawas Syariah (DPS).

Berdasarkan Fatwa Dewan Syariah Nasional Nomor: 20/DSN-MUI/IV/2001, mekanisme operasional reksadana syariah adalah sebagai berikut:

1) Mekanisme operasional dalam reksadana syariah

a) Antara pemodal dengan Manajer Investasi dilakukan dengan sistem wakalah.

b) Antara Manajer Investasai dan pengguna investasi dilakukan dengan sistem mudharabah.

2) Karakteristik sistem mudharabah yaitu sebagai berikut:

a) Pembagian keuntungan antara pemodal (shahibul mal) yang diwakili oleh Manajer Investasi dan pengguna investasi berdasarkan proporsi yang telah 
disepakati kedua belah pihak melalui Manajer Investasi sebagai wakil dan tidak ada jaminan atas hasil investasi tertentu kepada pemodal.

b) Pemodal hanya menanggung risiko sebesar dana yang telah diberikan.

c) Manajer Investasi sebagai wakil tidak menanggung risiko kerugian atas investasi yang dilakukan sepanjang bukan karena kelalaiannya (gross negligence/ tafrith) (Fatwa DSN MUI, 2001).

\section{d. Jenis dan Instrumen Investasi Reksadana Syariah}

Berdasarkan ketentuan Peraturan Otoritas Jasa Keuangan No. 19/POJK.04/2015, Tentang Penerbitan Dan Persyaratan Reksadana Syariah, jenis reksadana syariah antara lain:

1) Reksadana Syariah Pasar Uang;

2) Reksadana Syariah Pendapatan Tetap;

3) Reksadana Syariah Saham;

4) Reksadana Syariah Campuran;

5) Reksadana Syariah Terproteksi;

6) Reksadana Syariah Indeks;

7) Reksadana Syariah Berbasis Efek Syariah Luar Negeri;

8) Reksadana Syariah Berbasis Sukuk;

9) Reksadana Syariah Berbentuk Kontrak Investasi Kolektif yang Unit Penyertaannya diperdagangkan di Bursa; dan

10) Reksadana Syariah Berbentuk Kontrak Investasi Kolektif Penyertaan Terbatas

\subsubsection{Jakarta Islamic Index (JII)}

Jakarta Islamic Index (JII) adalah indeks saham syariah yang pertama kali diluncurkan di pasar modal Indonesia pada tanggal 3 Juli 2000. Konstituen JII hanya terdiri dari 30 saham syariah paling likuid yang tercatat di BEI. Sama seperti ISSI, review saham syariah yang menjadi konstituen JII dilakukan sebanyak dua kali dalam setahun, Mei dan November, mengikuti jadwal review DES oleh OJK.

Dalam rangka mengembangkan pasar modal syariah, BEI bersama dengan PT Danareksa Investment Management (DIM) meluncurkan indeks saham yang dibuat berdasarkan syariah Islam, yaitu Jakarta Islamic Index. Jakarta Islamic Index terdiri atas 30 jenis saham yang dipilih dari saham-saham yang sesuai dengan syariah Islam. JII dimaksudkan untuk digunakan sebagai tolak ukur untuk mengukur kinerja suatu investasi pada saham berbasis syariah. Melalui indeks diharapkan dapat meningkatkan kepercayaan investor untuk mengembangkan investasi dalam ekuiti secara syariah (Tan, 2013)

BEI menentukan dan melakukan seleksi saham syariah yang menjadi konstituen JII. Adapun kriteria likuditas yang digunakan dalam menyeleksi 30 saham syariah yang menjadi konstituen JII adalah sebagai berikut:

a. Saham syariah yang masuk dalam konstituen Indeks Saham Syariah Indonesia (ISSI) telah tercatat selama 6 bulan terakhir.

b. Dipilih 60 saham berdasarkan urutan rata-rata kapitalisasi pasar tertinggi selama 1 tahun terakhir.

c. Dari 60 saham tersebut, kemudian dipilih 30 saham berdasarkan rata-rata nilai transaksi harian di pasar regular tertinggi

d. 30 saham yang tersisa merupakan saham terpilih (JII, 2011).

Perubahan pada jenis usaha emiten akan dimonitor secara terus menerus berdasarkan data publik yang tersedia. Perusahaan yang mengubah lini bisnisnya 
sehingga menjadi tidak konsisten dengan prinsip syariah akan dikeluarkan dari indeks. Sedangkan saham emiten yang dikeluarkan akan diganti oleh saham emiten yang lain. Semua prosedur tersebut bertujuan untuk mengeliminasi adanya saham spekulatif (Buhanuddin, 2009).

\subsubsection{Metode Sharpe}

Sharpe merupakan alat ukur dari rasio pengembalian/risiko (reward/ratio risk) yang dikembangkan oleh William F. Sharpe (Fabozzi, 2010). Pengukuran dengan metode sharpe didasarkan atas apa yang disebut dengan premium atas risiko atau risk premium. Risk pemium adalah perbedaan (selisih) antara rata-rata kinerja yang dihasilkan oleh reksadana dan rata-rata kinerja bebas risiko (risk free asset) dengan risiko portofolio yang dinyatakan dengan standar deviasi (total risiko). Indikasinya adalah semakin tinggi nilai rasio Sharpe, maka semakin baik kinerjanya. Secara matematis indeks Sharpe dirumuskan sebagai berikut:

$$
\mathrm{Sp}=\underline{\mathrm{Rp}-\mathrm{Rf}}
$$

Keterangan:

- Sp = indeks kinerja Sharpe.

- Rp = return portofolio atau tingkat pengembalian pasar.

- $\mathrm{Rf}=$ return bebas risiko tingkat bunga bebas risiko.

- $\sigma p=$ total risiko yaitu hasil jumlah dari risiko sistematik dan risiko unsistematik.

Standar deviasi merupakan risiko fluktuasi reksadana yang dihasilkan karena berubah-ubahnya laba yang dihasilkan dari sub periode ke sub periode lainnya selama seluruh periode. Dalam teori portofolio, standar deviasi merupakan risiko total yang merupakan penjumlahan dari risiko pasar (systematic/market risk) dan unsystematic risk.

Dengan membagi risk premium dengan standar deviasi, sharpe mengukur risk premium yang dihasilkan per unit risiko yang diambil. Pengertianya sebagai berikut:

Investasi pada SBI tidak mengandung risiko dengan kinerja investasi tertentu. Investasi pada reksadana mengandung risiko sehingga diharapkan memberikan hasil investasi lebih besar dibandingkan dari pada investasi bebas risiko. Sharpe mengukur seberapa besar penambahan hasi investasi yang diperoleh (risk premium) untuk tiap unit risiko yang diambil. Semakin tinggi nilai rasio Sharpe semakin baik kinerja reksadana (Pratomo, 2009).

\subsubsection{Metode Treynor}

Dalam metode ini kinerja portofolio diukur dengan cara membandingkan antara premi risiko portofolio (yaitu selisih rata-rata tingkat pengembalian portofolio dengan rata-rata bebas risiko) dengan risiko portofolio yang dinyatakan dengan beta (risiko pasar atau risiko sistematis). Secara matematis indeks Treynor dirumuskan sebagai berikut:

$$
\mathrm{Tp}=\frac{\mathrm{Rp}-\mathrm{Rf}}{\beta \mathrm{p}}
$$

Keterangan:

- Tp = indeks kinerja Treynor.

- $\mathrm{Rp}=$ return portofolio atau tingkat pengembalian pasar.

- $\mathrm{Rf}=$ return bebas risiko tingkat bunga bebas risiko.

- $\beta p=$ risiko pasar dari portofolio atau risiko sistematik portofolio. (Halim, 2005) 
Pengukuran kinerja dengan metode Sharpe dan Treynor merupakan pelengkap satu dengan yang lainnya karena memberikan informasi yang berbeda. Portofolio yang tidak terdiversifikasi akan mendapat peringkat yang tinggi untuk Treynor namun peringkatnya lebih rendah untuk pengukuran Sharpe. Perbedaan peringkat pada kedua pengukuran diatas menunjukkan perbedaan baik buruknya diversifikasi portofolio tersebut relatif terhadap portofolio sejenis. Inilah perbedaannya dengan metode Sharpe yang menggunakan risiko total portofolio, sedangkan metode Treynor menggunakan risiko pasar. Oleh karena itu, kedua pengukuran tersebut sebaiknya dilakukan bersama (Kodrat dan Indonanjaya, 2010).

Seperti halnya metode Sharpe, semakin tinggi nilai rasio Treynor, maka semakin baik kinerja suatu reksadana.

\subsubsection{Metode Jensen}

Metode ini didasarkan pada konsep garis pasar sekuritas (security market lineSML) yang merupakan garis yang menghubungkan portofolio pasar dengan kesempatan investasi yang bebas risiko. Dalam keadaan ekuilibrium semua portofolio diharapkan berada pada SML. Jika terjadi penyimpangan artinya, jika dengan risiko yang sama tingkat pengembalian risiko portofolio berbeda dengan tingkat pengembalian pada SML, maka perbedaan tersebut disebut dengan indeks Jensen; di mana risikonya dinyatakan dalam beta (risiko pasar atau risiko sistematis). Apabila tingkat pengembalian aktual dari suatu portofolio lebih besar dari tingkat pengembalian yang sesuai dengan persamaan SML, berarti indeks Jensen akan bernilai positif, sebaliknya, apabila tingkat pengembalian aktual dari suatu portofolio lebih kecil dari tingkat pengembalian yang sesuai dengan persamaan SML, berarti indeks Jensen akan bernilai negatif.

Berdasarkan uraian diatas, maka indeks Jensen dapat dirumuskan sebagai berikut:

$$
\mathrm{Rp}-\mathrm{Rf}=\mathrm{ap}+\mathrm{bp}(\mathrm{Rm}-\mathrm{Rf})
$$

Persamaan diatas memperlihatkan adalah risiko premium portofolio dipengaruhi oleh risiko market premium. Nilai a dan b pada persamaan diatas diestimasikan sesuai dengan model yang dikenal dengan regresi. Oleh karenanya data asli runtun waktu dari portofolio, tingkat pengembalian pasar dan tingkat bunga bebas risiko harus tersedia. Nilai a yang tertinggi dan siginifikan merupakan portofolio yang terbaik dari portofolio yang ada.

\subsection{Metode Penelitian}

\subsubsection{Jenis dan Pendekatan}

Jenis penelitian ini adalah penelitian evaluatif. Penelitian evaluatif merupakan suatu desain dan prosedur evaluasi dalam mengumpulkan dan menganalisis data secara sistematik untuk menentukan nilai atau manfaat (worth) dari suatu praktik. Nilai atau manfaat dari suatu praktik didasarkan dari hasil pengumpulan data dengan menggunakan standar atau kriteria tertentu yang digunakan secara absolut maupun relatif. Penelitian evaluatif dirancang untuk menjawab pertanyaan, menguji atau membuktikan hipotesis (Sukmadinata, 2010)

Pendekatan yang digunakan dalam penelitian ini adalah pendekatan kuantitatif. Pendekatan kuantitatif adalah suatu proses dalam menemukan pengetahuan data berupa angka sebagai alat untuk menganalisis keterangan mengenai apa yang ingin 
kita ketahui (Kasiram, 2008). Karena dengan menggunakan data angka, data kuantitatif lebih mudah dimengerti bila dibandingkan dengan jenis data kualitatif.

\subsubsection{Populasi dan Sampel}

Populasi adalah wilayah generalisasi yang terdiri atas objek atau subjek yang mempunyai kuantitas dan karakteristik tertentu yang ditetapkan oleh peneliti untuk dipelajari dan kemudian ditarik kesimpulannya. Jadi populasi bukan hanya orang tetapi juga benda-benda alam yang lain. Populasi juga bukan sekedar jumlah yang ada pada objek atau subjek yang dipelajari, tetapi meliputi seluruh karakteristik atau sifat yang dimiliki oleh objek atau subjek tersebut (Sugiyono, 2014). Dalam penelitian ini, jumlah populasi yang digunakan dalam penelitian ini adalah seluruh reksadana syariah yang tercatat masih aktif di Pasar Modal Indonesia pada periode Januari 2017-Desember 2018.

Berdasarkan populasi tersebut dapat ditentukan sampel yang menjadi objek penelitian ini. Sampel adalah bagian dari jumlah dan karakteristik yang dimiliki oleh populasi (Teknik pengambilan sampel pada penelitian ini menggunakan purposive sampling yaitu pengambilan sampel bertujuan untuk mendapatkan sampel yang sesuai dengan kebutuhan dan kriteria penelitian. Kriteria sampel yang ditetapkan pada penelitian ini, antara lain:

1. Reksadana syariah yang tercatat masih aktif pada periode Januari 2017-Desember 2018, serta terdaftar di 0JK.

2. Jenis reksadana syariah merupakan reksadana saham syariah.

3. Sampel yang diambil merupakan produk dari perusahaan reksadana saham syariah yang aktif selama Januari 2017 sampai dengan Desember 2018 dan memiliki nilai aktiva bersih (NAB) yang dipublikasikan di media cetak.

Tabel. 2.1. Kriteria Perusahaan

\begin{tabular}{|c|c|c|c|c|}
\hline No. & Kriteria Sampel & $\begin{array}{c}\text { Melanggar } \\
\text { Sampel }\end{array}$ & $\begin{array}{l}\text { Jumlah } \\
\text { Sampel } \\
\end{array}$ & Total Sampel \\
\hline 1. & $\begin{array}{l}\text { Reksadana Syariah } \\
\text { yang tercatat masih } \\
\text { aktif pada periode } \\
\text { Januari 2017-Desember } \\
\text { 2018, serta terdaftar di } \\
\text { OJK }\end{array}$ & $\mathbf{0}$ & 224 & 224 \\
\hline 2. & $\begin{array}{lr}\text { Jenis } & \text { Reksadana } \\
\text { Syariah } & \text { merupakan } \\
\text { reksadana } & \text { saham } \\
\text { syariah. } & \\
\end{array}$ & 164 & 60 & 60 \\
\hline 3. & \begin{tabular}{lrr}
$\begin{array}{l}\text { Sampel yang } \\
\text { merupakan }\end{array}$ & $\begin{array}{r}\text { diambil } \\
\text { produk }\end{array}$ \\
dari & perusahaan \\
reksadana & saham \\
syariah yang & aktif \\
selama Januari & 2017 \\
sampai & \multicolumn{2}{c}{ dengan } \\
Desember 2018 dan \\
memiliki nilai & aktiva \\
bersih & (NAB) & yang
\end{tabular} & 37 & 23 & 23 \\
\hline
\end{tabular}




\begin{tabular}{|c|l|l|c|c|}
\hline & $\begin{array}{l}\text { dipublikasikan di } \\
\text { media cetak. }\end{array}$ & & \\
\hline $\mathbf{4}$ & $\begin{array}{l}\text { Jumlah sampel yang } \\
\text { memenuhi Kriteria }\end{array}$ & & & $\mathbf{2 3}$ \\
\hline $\mathbf{5}$ & Tahun Pengamatan & & & $\mathbf{2}$ \\
\hline
\end{tabular}

Sumber: OJK tahun 2018, data diolah peneliti

Dari kriteria-kriteria yang ditetapkan, maka dari 224 reksadana syariah yang dijadikan sampel penelitian ada 23 reksadana saham syariah.

Tabel 2.2. Sampel Penelitian Reksadana Saham Syariah

\begin{tabular}{|c|c|c|}
\hline No. & Reksadana & Manajer Investasi \\
\hline 1. & TRIM Syariah Saham & PT. Trimegah Asset Management \\
\hline 2 & Batavia Dana Saham Syariah & $\begin{array}{lll}\text { PT. Batavia } & \text { Prosperindo } & \text { Aset } \\
\text { Manajemen } & & \end{array}$ \\
\hline 3 & PNM Ekuitas Syariah & PT. PNM Investment Management \\
\hline 4 & 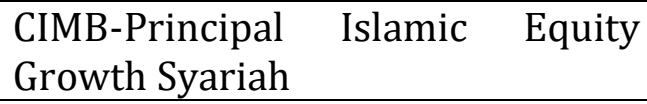 & PT. CIMB-Principal Asset Management \\
\hline 5 & Mandiri Investa Atraktif Syariah & PT. Mandiri Manajemen Investasi \\
\hline 6 & Manulife Syariah Sektoral Amanah & $\begin{array}{l}\text { PT. Manulife Aset Manajemen } \\
\text { Indonesia }\end{array}$ \\
\hline 7 & Panin Dana Syariah Saham & PT. Panin Asset Management \\
\hline 8 & MNC Dana Syariah Ekuitas & PT. MNC Asset Management \\
\hline 9 & SAM Sharia Equity Fund & PT. Samuel Aset Manajemen \\
\hline 10 & Lautandhana Saham Syariah & $\begin{array}{l}\text { PT. Lautandhana } \\
\text { Management }\end{array}$ \\
\hline 11 & Mandiri Investa Ekuitas Syariah & PT. Mandiri Manajemen Investasi \\
\hline 12 & OSO Syariah Equity Fund & PT. OSO Manajemen Investasi \\
\hline 13 & Avrist Equity 'Amar Syariah & PT. Avrist Asset Management \\
\hline 14 & Sucorinvest Sharia Equity Fund & PT. Sucorinvest Asset Management \\
\hline 15 & Danareksa Syariah Saham & $\begin{array}{l}\text { PT. Danareksa } \\
\text { Management }\end{array}$ \\
\hline 16 & HPAM Syariah Ekuitas & PT. Henan Putihrai Asset Management \\
\hline 17 & Simas Syariah Unggulan & PT. Sinarmas Asset Management \\
\hline 18 & Pratama Syariah & $\begin{array}{lll}\text { PT. Pratama } & \text { Capital } & \text { Assets } \\
\text { Management }\end{array}$ \\
\hline 19 & Bahana Icon Syariah & $\begin{array}{l}\text { PT. Bahana } \\
\text { Management }\end{array}$ \\
\hline 20 & Pacific Saham Syariah & PT. Pacific Capital Investment \\
\hline 21 & Maybank Syariah Equity Fund & PT. Maybank GMT Asset Management \\
\hline 22 & $\begin{array}{l}\text { BNI-AM Dana Saham Syariah } \\
\text { Musahamah }\end{array}$ & PT. BNI Asset Management \\
\hline 23 & KAM Kapital Syariah & PT. Kharisma Asset Management \\
\hline
\end{tabular}

Sumber: OJK tahun 2018 


\subsubsection{Definisi Operasional Pengukuran dan Variabel Penelitian}

Variabel-variabel operasional yang digunakan dalam penelitian ini yaitu sebagai berikut:

\section{Return Reksadana}

Return reksadana saham syariah diperoleh dari nilai NAB per unit untuk masing-masing reksadana saham syariah.

2. Rata-rata Return Investasi Bebas Risiko

Pada penelitian ini SBIS rate sebagai risk free rate.

3. Tingkat Pengembalian Pasar

Suatu ukuran kemampuan kinerja pasar sebagai pembandingnya, dalam menunjukkan suatu kinerja yang telah dicapai dalam periode tertentu yang diperhitungkan dari nilai JII.

4. Standar Deviasi

Standar deviasi menunjukkan penyimpangan yang terjadi dari rata-rata kinerja reksadana saham yang dihasilkan.

\section{HASIL DAN PEMBAHASAN}

\subsection{Hasil Analisis Data}

\subsubsection{Hasil Perhitungan Kinerja Reksadana Saham Syariah dengan Metode Sharpe}

Dari hasil perhitungan kinerja reksadana saham syariah TRIM Syariah Saham dengan metode sharpe diperoleh nilai sharpe sebesar 0,1418. Hasil tersebut menunjukkan bahwa return yang dihasilkan adalah positif dan kinerja reksadana saham syariah tersebut mampu melebihi risikonya (standar deviasi) yaitu sebesar 0,0134. Semakin besar nilai sharpe yang dihasilkan maka semakin baik pula kinerja portofolio suatu reksadana, dengan syarat mampu memberikan return diatas risiko individual (standar deviasi) yang ditanggungnya. Jadi, lebih baik berinvestasi di portofolio reksadana yang tidak memiliki risiko atau risikonya berada dibawah return yang dihasilkan sehingga mampu mengatasi risiko tersebut daripada berinvestasi pada portofolio reksadana yang berisiko.

Untuk data hasil perhitungan kinerja reksadana saham syariah dengan metode sharpe pada periode 2017 selengkapnya dapat dilihat pada tabel berikut:

Tabel 3.1. Data hasil perhitungan kinerja reksadana saham syariah dengan metode sharpe pada periode 2017

\begin{tabular}{|c|c|c|c|c|c|}
\hline \multirow{2}{*}{$\begin{array}{c}\text { Reksadana Saham } \\
\text { Syariah }\end{array}$} & \multicolumn{5}{|c|}{2017} \\
\hline & $\begin{array}{c}\text { Rata- } \\
\text { Rata } \\
\text { Return }\end{array}$ & $\begin{array}{c}\text { Rata- } \\
\text { rata } \\
\text { Return } \\
\text { Bebas } \\
\text { Resiko }\end{array}$ & $\begin{array}{l}\text { Standar } \\
\text { Deviasi }\end{array}$ & Sharpe & Kinerja \\
\hline $\begin{array}{l}\text { TRIM Syariah } \\
\text { Saham }\end{array}$ & 0,0067 & 0,0048 & 0,0134 & 0,1418 & Positif \\
\hline $\begin{array}{l}\text { Batavia Dana } \\
\text { Saham Syariah }\end{array}$ & 0,0048 & 0,0048 & 0,0158 & $\mathbf{0}$ & Positif \\
\hline PNM Ekuitas & 0,0043 & 0,0048 & 0,0152 & $-0,0329$ & Negatif \\
\hline
\end{tabular}




\begin{tabular}{|c|c|c|c|c|c|}
\hline Syariah & & & & & \\
\hline $\begin{array}{l}\text { CIMB-Principal } \\
\text { Islamic Equity } \\
\text { Growth Syariah }\end{array}$ & 0,0002 & 0,0048 & 0,0141 & $-0,3262$ & Negatif \\
\hline $\begin{array}{l}\text { Mandiri Investa } \\
\text { Atraktif Syariah }\end{array}$ & 0,0011 & 0,0048 & 0,0121 & $-0,3058$ & Negatif \\
\hline $\begin{array}{l}\text { Manulife Syariah } \\
\text { Sektoral Amanah }\end{array}$ & 0,0012 & 0,0048 & 0,0149 & $-0,2416$ & Negatif \\
\hline $\begin{array}{l}\text { Panin Dana } \\
\text { Syariah Saham }\end{array}$ & $-0,0004$ & 0,0048 & 0,0178 & $-0,2921$ & Negatif \\
\hline $\begin{array}{l}\text { MNC Dana Syariah } \\
\text { Ekuitas }\end{array}$ & 0,0086 & 0,0048 & 0,0297 & 0,1279 & Positif \\
\hline $\begin{array}{l}\text { SAM Sharia Equity } \\
\text { Fund }\end{array}$ & -0.0090 & 0,0048 & 0,0271 & $-0,5092$ & Negatif \\
\hline $\begin{array}{l}\text { Lautandhana } \\
\text { Saham Syariah }\end{array}$ & 0,0030 & 0,0048 & 0,0164 & $-0,1098$ & Negatif \\
\hline $\begin{array}{l}\text { Mandiri Investa } \\
\text { Ekuitas Syariah }\end{array}$ & 0,0027 & 0,0048 & 0,0112 & $-0,1875$ & Negatif \\
\hline $\begin{array}{l}\text { OSO Syariah Equity } \\
\text { Fund }\end{array}$ & $-0,0163$ & 0,0048 & 0,0305 & $-0,6918$ & Negatif \\
\hline $\begin{array}{l}\text { Avrist Equity Amar } \\
\text { Syariah }\end{array}$ & 0,0007 & 0,0048 & 0,0173 & $-0,237$ & Negatif \\
\hline $\begin{array}{l}\text { Sucorinvest Sharia } \\
\text { Equity Fund }\end{array}$ & 0,0163 & 0,0048 & 0,0269 & 0,4275 & Positif \\
\hline $\begin{array}{l}\text { Danareksa Syariah } \\
\text { Saham }\end{array}$ & 0,000025 & 0,0048 & 0,0149 & -0.3205 & Negatif \\
\hline $\begin{array}{l}\text { HPAM Syariah } \\
\text { Ekuitas }\end{array}$ & 0,0059 & 0,0048 & 0,0378 & 0,0291 & Positif \\
\hline $\begin{array}{l}\text { Simas Syariah } \\
\text { Unggulan }\end{array}$ & $-0,0085$ & 0,0048 & 0,0233 & $-0,5708$ & Negatif \\
\hline Pratama Syariah & 0,0047 & 0,0048 & 0,0371 & $-0,0027$ & Negatif \\
\hline $\begin{array}{l}\text { Bahana Icon } \\
\text { Syariah }\end{array}$ & 0,0019 & 0,0048 & 0,0168 & $-0,1726$ & Negatif \\
\hline $\begin{array}{l}\text { Pacific Saham } \\
\text { Syariah }\end{array}$ & 0,0107 & 0,0048 & 0,0416 & 0,1418 & Positif \\
\hline $\begin{array}{l}\text { Maybank Syariah } \\
\text { Equity Fund }\end{array}$ & 0,0033 & 0,0048 & 0,0172 & $-0,0872$ & Negatif \\
\hline $\begin{array}{l}\text { BNI-AM Dana } \\
\text { Saham Syariah } \\
\text { Musahamah }\end{array}$ & 0,0019 & 0,0048 & 0,0164 & $-0,1768$ & Negatif \\
\hline $\begin{array}{l}\text { KAM Kapital } \\
\text { Syariah }\end{array}$ & 0,0263 & 0,0048 & 0,0851 & 0,2526 & Positif \\
\hline
\end{tabular}

Sumber: OJK tahun 2017, data diolah peneliti

Untuk data hasil perhitungan kinerja reksadana saham syariah dengan metode sharpe pada periode 2018 selengkapnya dapat dilihat pada tabel berikut: 
Tabel 3.2. Data hasil perhitungan kinerja reksadana saham syariah dengan metode sharpe pada periode 2018

\begin{tabular}{|c|c|c|c|c|c|}
\hline \multirow{2}{*}{$\begin{array}{c}\text { Reksadana } \\
\text { Saham Syariah }\end{array}$} & \multicolumn{5}{|c|}{2018} \\
\hline & $\begin{array}{l}\text { Rata-Rata } \\
\text { Return }\end{array}$ & $\begin{array}{c}\text { Rata- } \\
\text { rata } \\
\text { Return } \\
\text { Bebas } \\
\text { Resiko }\end{array}$ & $\begin{array}{l}\text { Standar } \\
\text { Deviasi }\end{array}$ & Sharpe & Kinerja \\
\hline $\begin{array}{l}\text { TRIM Syariah } \\
\text { Saham }\end{array}$ & $-0,0015$ & 0,005 & 0,0399 & $-0,1629$ & Negatif \\
\hline $\begin{array}{l}\text { Batavia Dana } \\
\text { Saham Syariah }\end{array}$ & $-0,0047$ & 0,005 & 0,0412 & $-0,2354$ & Negatif \\
\hline $\begin{array}{l}\text { PNM Ekuitas } \\
\text { Syariah }\end{array}$ & $-0,0065$ & 0,005 & 0,0450 & $-0,2556$ & Negatif \\
\hline $\begin{array}{l}\text { CIMB-Principal } \\
\text { Islamic Equity } \\
\text { Growth Syariah }\end{array}$ & $-0,0040$ & 0,005 & 0,0358 & $-0,2514$ & Negatif \\
\hline $\begin{array}{l}\text { Mandiri Investa } \\
\text { Atraktif Syariah }\end{array}$ & $-0,0054$ & 0,005 & 0,0377 & $-0,2759$ & Negatif \\
\hline $\begin{array}{l}\text { Manulife Syariah } \\
\text { Sektoral Amanah }\end{array}$ & $-0,0056$ & 0,005 & 0,0427 & $-0,2482$ & Negatif \\
\hline $\begin{array}{l}\text { Panin Dana } \\
\text { Syariah Saham }\end{array}$ & $-0,0065$ & 0,005 & 0,0414 & $-0,2778$ & Negatif \\
\hline $\begin{array}{l}\text { MNC Dana } \\
\text { Syariah Ekuitas }\end{array}$ & $-0,0047$ & 0,005 & 0,0378 & $-0,2566$ & Negatif \\
\hline $\begin{array}{l}\text { SAM Sharia } \\
\text { Equity Fund }\end{array}$ & $-0,0062$ & 0,005 & 0,0477 & $-0,2348$ & Negatif \\
\hline $\begin{array}{l}\text { Lautandhana } \\
\text { Saham Syariah }\end{array}$ & $-0,0061$ & 0,005 & 0,0364 & $-0,3049$ & Negatif \\
\hline $\begin{array}{l}\text { Mandiri Investa } \\
\text { Ekuitas Syariah }\end{array}$ & $-0,0058$ & 0,005 & 0,0379 & $-0,285$ & Negatif \\
\hline $\begin{array}{l}\text { OSO Syariah } \\
\text { Equity Fund }\end{array}$ & $-0,0315$ & 0,005 & 0,0603 & $-0,6053$ & Negatif \\
\hline $\begin{array}{l}\text { Avrist Equity } \\
\text { Amar Syariah }\end{array}$ & $-0,0056$ & 0,005 & 0,0408 & $-0,2598$ & Negatif \\
\hline $\begin{array}{l}\text { Sucorinvest } \\
\text { Sharia Equity } \\
\text { Fund }\end{array}$ & 0,0107 & 0,005 & 0,0465 & 0,1226 & Positif \\
\hline $\begin{array}{l}\text { Danareksa } \\
\text { Syariah Saham }\end{array}$ & $-0,0037$ & 0,005 & 0,0458 & $-0,19$ & Negatif \\
\hline $\begin{array}{l}\text { HPAM Syariah } \\
\text { Ekuitas }\end{array}$ & $-0,0183$ & 0,005 & 0,0884 & $-0,2636$ & Negatif \\
\hline $\begin{array}{l}\text { Simas Syariah } \\
\text { Unggulan }\end{array}$ & 0,0260 & 0,005 & 0,0708 & 0,2966 & Positif \\
\hline Pratama Syariah & $-0,0073$ & 0,005 & 0,0497 & $-0,2475$ & Negatif \\
\hline $\begin{array}{l}\text { Bahana Icon } \\
\text { Syariah }\end{array}$ & $-0,0044$ & 0,005 & 0,0440 & $-0,2136$ & Negatif \\
\hline Pacific Saham & 0,0078 & 0,005 & 0,0285 & 0,0982 & Positif \\
\hline
\end{tabular}




\begin{tabular}{|l|l|l|l|l|l|}
\hline Syariah & & & & & \\
\hline $\begin{array}{l}\text { Maybank Syariah } \\
\text { Equity Fund }\end{array}$ & $-0,0117$ & 0,005 & 0,0553 & $-0,302$ & Negatif \\
\hline $\begin{array}{l}\text { BNI-AM Dana } \\
\text { Saham Syariah } \\
\text { Musahamah }\end{array}$ & $-0,0092$ & 0,005 & 0,0434 & $-0,3272$ & Negatif \\
\hline $\begin{array}{l}\text { KAM Kapital } \\
\text { Syariah }\end{array}$ & $-0,0103$ & 0,005 & 0,0523 & $-0,2925$ & Negatif \\
\hline
\end{tabular}

Sumber: OJK tahun 2018, data diolah peneliti

\subsubsection{Hasil Perhitungan Kinerja Reksadana Saham Syariah dengan Metode Treynor}

Berdasarkan hasil perhitungan kinerja reksadana saham syariah TRIM Syariah Saham periode 2017 dengan metode treynor diperoleh nilai treynor sebesar 0,0014. Hasil tersebut menunjukkan bahwa return yang dihasilkan adalah positif namun berada di bawah kinerja treynor pasar (pasar agregat) yaitu sebesar 0,0029 (pada periode 2017 dapat dilihat pada tabel 3.3.) sehingga reksadana tersebut masih belum bisa mengatasi risiko sistematis (pasar) yang di tanggungnya.

Semakin tinggi nilai treynor yang dihasilkan, maka semakin baik kinerja portofolionya, dengan syarat return/ nilai rasio yang diberikan mampu melebihi nilai risiko sistematis (treynor pasar). Jadi, lebih baik berinvestasi di portofolio reksadana yang tidak memiliki risiko atau risikonya berada dibawah return yang dihasilkan sehingga mampu mengatasi risiko tersebut daripada berinvestasi pada portofolio reksadana yang penuh dengan risiko.

Hasil perhitungan kinerja reksadana saham syariah dengan metode treynor pada periode 2017 selengkapnya dapat dilihat pada tabel berikut:

Tabel 3.3. Hasil Perhitungan Kinerja Reksadana Saham Syariah dengan Metode Treynor Periode 2017

\begin{tabular}{|c|c|c|c|c|c|}
\hline \multirow{2}{*}{$\begin{array}{c}\text { Reksadana } \\
\text { Saham Syariah }\end{array}$} & \multicolumn{5}{|c|}{2017} \\
\hline & $\begin{array}{l}\text { Rata-Rata } \\
\text { Return }\end{array}$ & $\begin{array}{c}\text { Rata- } \\
\text { rata } \\
\text { Return } \\
\text { Bebas } \\
\text { Resiko }\end{array}$ & $\begin{array}{r}\text { Standar } \\
\text { Deviasi }\end{array}$ & Sharpe & Kinerja \\
\hline $\begin{array}{l}\text { TRIM Syariah } \\
\text { Saham }\end{array}$ & 0,0067 & 0,0048 & 1,3104 & 0,0014 & Positif \\
\hline $\begin{array}{l}\text { Batavia Dana } \\
\text { Saham Syariah }\end{array}$ & 0,0048 & 0,0048 & 1,2577 & $\mathbf{0}$ & Positif \\
\hline $\begin{array}{l}\text { PNM Ekuitas } \\
\text { Syariah }\end{array}$ & 0,0043 & 0,0048 & 0,7271 & $-0,0007$ & Negatif \\
\hline $\begin{array}{l}\text { CIMB-Principal } \\
\text { Islamic Equity } \\
\text { Growth Syariah }\end{array}$ & 0,0002 & 0,0048 & 1,3219 & $-0,0035$ & Negatif \\
\hline $\begin{array}{l}\text { Mandiri Investa } \\
\text { Atraktif Syariah }\end{array}$ & 0,0011 & 0,0048 & 1,5362 & $-0,0024$ & Negatif \\
\hline $\begin{array}{l}\text { Manulife Syariah } \\
\text { Sektoral Amanah }\end{array}$ & 0,0012 & 0,0048 & 0,9637 & $-0,0037$ & Negatif \\
\hline
\end{tabular}




\begin{tabular}{|c|c|c|c|c|c|}
\hline $\begin{array}{l}\text { Panin Dana } \\
\text { Syariah Saham }\end{array}$ & $-0,0004$ & 0,0048 & 0,7624 & $-0,0068$ & Negatif \\
\hline $\begin{array}{l}\text { MNC Dana } \\
\text { Syariah Ekuitas }\end{array}$ & 0,0086 & 0,0048 & $-0,1969$ & $-0,0193$ & Negatif \\
\hline $\begin{array}{l}\text { SAM Sharia } \\
\text { Equity Fund }\end{array}$ & $-0,0090$ & 0,0048 & 0,2304 & $-0,0599$ & Negatif \\
\hline $\begin{array}{l}\text { Lautandhana } \\
\text { Saham Syariah }\end{array}$ & 0,0030 & 0,0048 & 0,7287 & $-0,0025$ & Negatif \\
\hline $\begin{array}{l}\text { Mandiri Investa } \\
\text { Ekuitas Syariah }\end{array}$ & 0,0027 & 0,0048 & 1,7246 & $-0,0012$ & Negatif \\
\hline $\begin{array}{l}\text { OSO Syariah } \\
\text { Equity Fund }\end{array}$ & $-0,0163$ & 0,0048 & 0,0941 & $-0,2242$ & Negatif \\
\hline $\begin{array}{l}\text { Avrist Equity } \\
\text { Amar Syariah }\end{array}$ & 0,0007 & 0,0048 & 0,7538 & $-0,0054$ & Negatif \\
\hline $\begin{array}{l}\text { Sucorinvest } \\
\text { Sharia Equity } \\
\text { Fund }\end{array}$ & 0,0163 & 0,0048 & 0,2487 & 0,0462 & Positif \\
\hline $\begin{array}{l}\text { Danareksa } \\
\text { Syariah Saham }\end{array}$ & 0,000025 & 0,0048 & 0,8149 & $-0,0059$ & Negatif \\
\hline $\begin{array}{l}\text { HPAM Syariah } \\
\text { Ekuitas }\end{array}$ & 0,0059 & 0,0048 & 0,3513 & 0,0031 & Positif \\
\hline $\begin{array}{l}\text { Simas Syariah } \\
\text { Unggulan }\end{array}$ & $-0,0085$ & 0,0048 & 0,0242 & $-0,5496$ & Negatif \\
\hline Pratama Syariah & 0,0047 & 0,0048 & $-0,1655$ & 0,0006 & Positif \\
\hline $\begin{array}{l}\text { Bahana Icon } \\
\text { Syariah }\end{array}$ & 0,0019 & 0,0048 & 0,8881 & $-0,0033$ & Negatif \\
\hline $\begin{array}{l}\text { Pacific Saham } \\
\text { Syariah }\end{array}$ & 0,0107 & 0,0048 & 0,0999 & 0,0591 & Positif \\
\hline $\begin{array}{l}\text { Maybank Syariah } \\
\text { Equity Fund }\end{array}$ & 0,0033 & 0,0048 & 0,6213 & $-0,0024$ & Negatif \\
\hline $\begin{array}{l}\text { BNI-AM Dana } \\
\text { Saham Syariah } \\
\text { Musahamah }\end{array}$ & 0,0019 & 0,0048 & 1,0405 & $-0,0028$ & Negatif \\
\hline $\begin{array}{l}\text { KAM Kapital } \\
\text { Syariah }\end{array}$ & 0,0263 & 0,0048 & 0,1790 & 0,1201 & Positif \\
\hline $\begin{array}{l}\text { JII (Treynor } \\
\text { Pasar) }\end{array}$ & 0,0077 & 0,0048 & 1 & 0,0029 & Positif \\
\hline
\end{tabular}

Sumber: OJK tahun 2017, data diolah peneliti

Untuk data hasil perhitungan kinerja reksadana saham syariah dengan metode treynor pada periode 2018 selengkapnya dapat dilihat pada tabel berikut:

Tabel. 3.4. Hasil Perhitungan Kinerja Reksadana Saham Syariah dengan Metode Treynor Periode 2018

\begin{tabular}{|c|c|c|c|c|c|}
\hline \multirow{2}{*}{$\begin{array}{c}\text { Reksadana } \\
\text { Saham Syariah }\end{array}$} & \multicolumn{5}{|c|}{2018} \\
\hline & $\begin{array}{c}\text { Rata-Rata } \\
\text { Return }\end{array}$ & $\begin{array}{c}\text { Rata- } \\
\text { rata } \\
\text { Return } \\
\text { Bebas }\end{array}$ & $\begin{array}{l}\text { Standar } \\
\text { Deviasi }\end{array}$ & Sharpe & Kinerja \\
\hline
\end{tabular}




\begin{tabular}{|c|c|c|c|c|c|}
\hline & & Resiko & & & \\
\hline $\begin{array}{l}\text { TRIM Syariah } \\
\text { Saham }\end{array}$ & $-0,0015$ & 0,005 & 0,6066 & $-0,0107$ & Negatif \\
\hline $\begin{array}{l}\text { Batavia Dana } \\
\text { Saham Syariah }\end{array}$ & $-0,0047$ & 0,005 & 0,6174 & $-0,0157$ & Negatif \\
\hline $\begin{array}{l}\text { PNM Ekuitas } \\
\text { Syariah }\end{array}$ & $-0,0065$ & 0,005 & 0,6331 & $-0,0182$ & Negatif \\
\hline $\begin{array}{l}\text { CIMB-Principal } \\
\text { Islamic Equity } \\
\text { Growth Syariah }\end{array}$ & $-0,0040$ & 0,005 & 0,7645 & $-0,0118$ & Negatif \\
\hline $\begin{array}{l}\text { Mandiri Investa } \\
\text { Atraktif Syariah }\end{array}$ & $-0,0054$ & 0,005 & 0,7372 & $-0,0141$ & Negatif \\
\hline $\begin{array}{l}\text { Manulife Syariah } \\
\text { Sektoral Amanah }\end{array}$ & $-0,0056$ & 0,005 & 0,5931 & $-0,0179$ & Negatif \\
\hline $\begin{array}{l}\text { Panin Dana } \\
\text { Syariah Saham }\end{array}$ & $-0,0065$ & 0,005 & 0,5864 & $-0,0196$ & Negatif \\
\hline $\begin{array}{l}\text { MNC Dana } \\
\text { Syariah Ekuitas }\end{array}$ & $-0,0047$ & 0,005 & 0,6714 & $-0,0144$ & Negatif \\
\hline $\begin{array}{l}\text { SAM Sharia } \\
\text { Equity Fund }\end{array}$ & $-0,0062$ & 0,005 & 0,4784 & $-0,0234$ & Negatif \\
\hline $\begin{array}{l}\text { Lautandhana } \\
\text { Saham Syariah }\end{array}$ & $-0,0061$ & 0,005 & 0,8121 & $-0,0137$ & Negatif \\
\hline $\begin{array}{l}\text { Mandiri Investa } \\
\text { Ekuitas Syariah }\end{array}$ & $-0,0058$ & 0,005 & 0,7404 & $-0,0146$ & Negatif \\
\hline $\begin{array}{l}\text { OSO Syariah } \\
\text { Equity Fund }\end{array}$ & $-0,0315$ & 0,005 & 0,2679 & $-0,1362$ & Negatif \\
\hline $\begin{array}{l}\text { Avrist Equity } \\
\text { Amar Syariah }\end{array}$ & $-0,0056$ & 0,005 & 0,7216 & $-0,0147$ & Negatif \\
\hline $\begin{array}{l}\text { Sucorinvest } \\
\text { Sharia Equity } \\
\text { Fund }\end{array}$ & 0,0107 & 0,005 & 0,2852 & 0,02 & Positif \\
\hline $\begin{array}{l}\text { Danareksa } \\
\text { Syariah Saham }\end{array}$ & $-0,0037$ & 0,005 & 0,5383 & $-0,0162$ & Negatif \\
\hline $\begin{array}{l}\text { HPAM Syariah } \\
\text { Ekuitas }\end{array}$ & $-0,0183$ & 0,005 & 0,0665 & $-0,3504$ & Negatif \\
\hline $\begin{array}{l}\text { Simas Syariah } \\
\text { Unggulan }\end{array}$ & 0,0260 & 0,005 & 0,1240 & 0,1694 & Positif \\
\hline Pratama Syariah & $-0,0073$ & 0,005 & 0,4615 & $-0,0267$ & Negatif \\
\hline $\begin{array}{l}\text { Bahana Icon } \\
\text { Syariah }\end{array}$ & $-0,0044$ & 0,005 & 0,6125 & $-0,0153$ & Negatif \\
\hline $\begin{array}{l}\text { Pacific Saham } \\
\text { Syariah }\end{array}$ & 0,0078 & 0,005 & 0,3375 & 0,0083 & Positif \\
\hline $\begin{array}{l}\text { Maybank Syariah } \\
\text { Equity Fund }\end{array}$ & $-0,0117$ & 0,005 & 0,3615 & $-0,0462$ & Negatif \\
\hline $\begin{array}{l}\text { BNI-AM Dana } \\
\text { Saham Syariah } \\
\text { Musahamah }\end{array}$ & $-0,0092$ & 0,005 & 0,5880 & $-0,0241$ & Negatif \\
\hline KAM Kapital & $-0,0103$ & 0,005 & 0,0068 & $-2,25$ & Negatif \\
\hline
\end{tabular}




\begin{tabular}{|l|l|l|l|l|l|}
\hline Syariah & & & & & \\
\hline $\begin{array}{l}\text { JII (Treynor } \\
\text { Pasar) }\end{array}$ & $-0,0080$ & 0,005 & 1 & $-0,013$ & Negatif \\
\hline
\end{tabular}

Sumber: OJK tahun 2018, data diolah peneliti

\subsubsection{Hasil Perhitungan Kinerja Reksadana Saham Syariah dengan Metode Jensen}

Berdasarkan hasil perhitungan kinerja reksadana saham syariah TRIM Syariah Saham periode 2017 dengan metode jensen diperoleh nilai jensen sebesar -0,0019. Hasil tersebut menunjukkan bahwa nilai yang dihasilkan adalah negatif. Hal ini berarti bahwa reksadana tersebut memiliki kinerja inferior terhadap pasar. Karena premi risiko portofolio reksadana tersebut yaitu sebesar 0,0019 (Rp-Rf =0,0067-0,0048 =0,0019) berada di bawah nilai premi risiko pasarnya yaitu sebesar $0,0029(\mathrm{Rm}-\mathrm{Rf}=0,0077-0,0048=0,0029)$ sehingga kinerja reksadana tersebut dapat dikatakan inferior atau dibawah pasar (berisiko).

Jika nilai jensen yang diperoleh positif maka kinerja suatu reksadana saham syariah adalah baik/ superior terhadap pasar dengan syarat nilai dari premi risiko portofolionya harus mampu melebihi dari nilai premi risiko pasarnya sehingga nantinya dapat memberikan actual return yang lebih tinggi daripada return yang diharapkan. Dan jika nilai jensen yang diperoleh negatif maka kinerja suatu reksadana saham syariah adalah kurang baik/ inferior terhadap pasar (berisiko). Jadi, lebih baik berinvestasi pada portofolio reksadana saham syariah yang memiliki kinerja/ nilai jensen yang positif dan nilai premi risiko portofolionya mampu melebihi premi risiko pasarnya daripada berinvestasi pada reksadana yang bernilai negatif karena nantinya mampu memberikan actual return yang lebih tinggi daripada return yang diharapkan dan juga sebaliknya.

Hasil perhitungan kinerja reksadana saham syariah dengan metode Jensen pada periode 2017 selengkapnya dapat dilihat pada tabel berikut:

Tabel. 3.5. Hasil Perhitungan Kinerja Reksadana Saham Syariah dengan Metode Jensen Periode 2017

\begin{tabular}{|c|c|c|c|c|c|}
\hline \multirow{2}{*}{$\begin{array}{c}\text { Reksadana } \\
\text { Saham Syariah }\end{array}$} & \multicolumn{5}{|c|}{2017} \\
\hline & $\begin{array}{c}\text { Rata-Rata } \\
\text { Return }\end{array}$ & $\begin{array}{c}\text { Rata- } \\
\text { rata } \\
\text { Return } \\
\text { Bebas } \\
\text { Resiko } \\
\end{array}$ & $\begin{array}{l}\text { Standar } \\
\text { Deviasi }\end{array}$ & Sharpe & Kinerja \\
\hline $\begin{array}{l}\text { TRIM Syariah } \\
\text { Saham }\end{array}$ & 0,0067 & 0,0048 & 1,3104 & $-0,0019$ & Negatif \\
\hline $\begin{array}{l}\text { Batavia Dana } \\
\text { Saham Syariah }\end{array}$ & 0,0048 & 0,0048 & 1,2577 & $-0,0036$ & Negatif \\
\hline $\begin{array}{l}\text { PNM Ekuitas } \\
\text { Syariah }\end{array}$ & 0,0043 & 0,0048 & 0,7271 & $-0,0026$ & Negatif \\
\hline $\begin{array}{l}\text { CIMB-Principal } \\
\text { Islamic Equity } \\
\text { Growth Syariah }\end{array}$ & 0,0002 & 0,0048 & 1,3219 & $-0,0084$ & Negatif \\
\hline Mandiri Investa & 0,0011 & 0,0048 & 1,5362 & $-0,0082$ & Negatif \\
\hline
\end{tabular}




\begin{tabular}{|c|c|c|c|c|c|}
\hline Atraktif Syariah & & & & & \\
\hline $\begin{array}{l}\text { Manulife Syariah } \\
\text { Sektoral Amanah }\end{array}$ & 0,0012 & 0,0048 & 0,9637 & $-0,0064$ & Negatif \\
\hline $\begin{array}{l}\text { Panin Dana } \\
\text { Syariah Saham }\end{array}$ & $-0,0004$ & 0,0048 & 0,7642 & $-0,0074$ & Negatif \\
\hline $\begin{array}{l}\text { MNC Dana } \\
\text { Syariah Ekuitas }\end{array}$ & 0,0086 & 0,0048 & $-0,1969$ & 0,0044 & Positif \\
\hline $\begin{array}{l}\text { SAM Sharia } \\
\text { Equity Fund }\end{array}$ & $-0,0090$ & 0,0048 & 0,2304 & $-0,0145$ & Negatif \\
\hline $\begin{array}{l}\text { Lautandhana } \\
\text { Saham Syariah }\end{array}$ & 0,0030 & 0,0048 & 0,7287 & $-0,0039$ & Negatif \\
\hline $\begin{array}{l}\text { Mandiri Investa } \\
\text { Ekuitas Syariah }\end{array}$ & 0,0027 & 0,0048 & 1,7246 & $-0,0071$ & Negatif \\
\hline $\begin{array}{l}\text { OSO Syariah } \\
\text { Equity Fund }\end{array}$ & $-0,0163$ & 0,0048 & 0,0941 & $-0,0214$ & Negatif \\
\hline $\begin{array}{l}\text { Avrist Equity } \\
\text { Amar Syariah }\end{array}$ & 0,0007 & 0,0048 & 0,7538 & $-0,0063$ & Negatif \\
\hline $\begin{array}{l}\text { Sucorinvest } \\
\text { Sharia Equity } \\
\text { Fund } \\
\end{array}$ & 0,0163 & 0,0048 & 0,2487 & 0,0108 & Positif \\
\hline $\begin{array}{l}\text { Danareksa } \\
\text { Syariah Saham }\end{array}$ & 0,000025 & 0,0048 & 0,8149 & $-0,0071$ & Negatif \\
\hline $\begin{array}{l}\text { HPAM Syariah } \\
\text { Ekuitas }\end{array}$ & 0,0059 & 0,0048 & 0,3513 & 0,00008 & Positif \\
\hline $\begin{array}{l}\text { Simas Syariah } \\
\text { Unggulan }\end{array}$ & $-0,0085$ & 0,0048 & 0,0242 & $-0,0134$ & Negatif \\
\hline Pratama Syariah & 0,0047 & 0,0048 & $-0,1655$ & 0,0004 & Positif \\
\hline $\begin{array}{l}\text { Bahana Icon } \\
\text { Syariah }\end{array}$ & 0,0019 & 0,0048 & 0,8881 & $-0,0055$ & Negatif \\
\hline $\begin{array}{l}\text { Pacific Saham } \\
\text { Syariah }\end{array}$ & 0,0107 & 0,0048 & 0,0999 & 0,0056 & Positif \\
\hline $\begin{array}{l}\text { Maybank Syariah } \\
\text { Equity Fund }\end{array}$ & 0,0033 & 0,0048 & 0,6213 & $-0,0033$ & Negatif \\
\hline $\begin{array}{l}\text { BNI-AM Dana } \\
\text { Saham Syariah } \\
\text { Musahamah }\end{array}$ & 0,0019 & 0,0048 & 1,0405 & $-0,0059$ & Negatif \\
\hline $\begin{array}{l}\text { KAM Kapital } \\
\text { Syariah }\end{array}$ & 0,0263 & 0,0048 & 0,1790 & 0,021 & Positif \\
\hline
\end{tabular}

Sumber: OJK tahun 2017, data diolah peneliti

Data hasil perhitungan kinerja reksadana saham syariah dengan metode jensen periode 2018 selengkapnya dapat dilihat pada tabel berikut:

Tabel 3.6. Hasil Perhitungan Kinerja Reksadana Saham Syariah dengan Metode Jensen Periode 2018

\begin{tabular}{|c|c|c|c|c|c|}
\hline Reksadana & \multicolumn{5}{|c|}{2018} \\
\cline { 2 - 5 } & $\begin{array}{c}\text { Rata-Rata } \\
\text { Return }\end{array}$ & $\begin{array}{c}\text { Rata- } \\
\text { rata } \\
\text { Return }\end{array}$ & $\begin{array}{c}\text { Standar } \\
\text { Deviasi }\end{array}$ & Sharpe & Kinerja \\
\hline
\end{tabular}




\begin{tabular}{|c|c|c|c|c|c|}
\hline & & $\begin{array}{l}\text { Bebas } \\
\text { Resiko }\end{array}$ & & & \\
\hline $\begin{array}{l}\text { TRIM Syariah } \\
\text { Saham }\end{array}$ & $-0,0015$ & 0,005 & 0,6066 & 0,0014 & Positif \\
\hline $\begin{array}{l}\text { Batavia Dana } \\
\text { Saham Syariah }\end{array}$ & $-0,0047$ & 0,005 & 0,6174 & $-0,0017$ & Negatif \\
\hline $\begin{array}{l}\text { PNM Ekuitas } \\
\text { Syariah }\end{array}$ & $-0,0065$ & 0,005 & 0,6331 & $-0,0033$ & Negatif \\
\hline $\begin{array}{l}\text { CIMB-Principal } \\
\text { Islamic Equity } \\
\text { Growth Syariah }\end{array}$ & $-0,0040$ & 0,005 & 0,7645 & 0,0009 & Positif \\
\hline $\begin{array}{l}\text { Mandiri Investa } \\
\text { Atraktif Syariah }\end{array}$ & $-0,0054$ & 0,005 & 0,7372 & $-0,0008$ & Negatif \\
\hline $\begin{array}{l}\text { Manulife Syariah } \\
\text { Sektoral Amanah }\end{array}$ & $-0,0056$ & 0,005 & 0,5931 & $-0,0029$ & Negatif \\
\hline $\begin{array}{l}\text { Panin Dana } \\
\text { Syariah Saham }\end{array}$ & $-0,0065$ & 0,005 & 0,5864 & $-0,0039$ & Negatif \\
\hline $\begin{array}{l}\text { MNC Dana } \\
\text { Syariah Ekuitas }\end{array}$ & $-0,0047$ & 0,005 & 0,6714 & $-0,002$ & Negatif \\
\hline $\begin{array}{l}\text { SAM Sharia } \\
\text { Equity Fund }\end{array}$ & $-0,0062$ & 0,005 & 0,4784 & $-0,005$ & Negatif \\
\hline $\begin{array}{l}\text { Lautandhana } \\
\text { Saham Syariah }\end{array}$ & $-0,0061$ & 0,005 & 0,8121 & $-0,0005$ & Negatif \\
\hline $\begin{array}{l}\text { Mandiri Investa } \\
\text { Ekuitas Syariah }\end{array}$ & $-0,0058$ & 0,005 & 0,7404 & $-0,0012$ & Negatif \\
\hline $\begin{array}{l}\text { OSO Syariah } \\
\text { Equity Fund }\end{array}$ & $-0,0315$ & 0,005 & 0,2679 & $-0,0330$ & Negatif \\
\hline $\begin{array}{l}\text { Avrist Equity } \\
\text { Amar Syariah }\end{array}$ & $-0,0056$ & 0,005 & 0,7216 & $-0,0012$ & Negatif \\
\hline $\begin{array}{l}\text { Sucorinvest } \\
\text { Sharia Equity } \\
\text { Fund }\end{array}$ & 0,0107 & 0,005 & 0,2852 & 0,0094 & Positif \\
\hline $\begin{array}{l}\text { Danareksa } \\
\text { Syariah Saham }\end{array}$ & $-0,0037$ & 0,005 & 0,5383 & $-0,0017$ & Negatif \\
\hline $\begin{array}{l}\text { HPAM Syariah } \\
\text { Ekuitas }\end{array}$ & $-0,0183$ & 0,005 & 0,0665 & $-0,0224$ & Negatif \\
\hline $\begin{array}{l}\text { Simas Syariah } \\
\text { Unggulan }\end{array}$ & 0,0260 & 0,005 & 0,1240 & 0,0226 & Positif \\
\hline Pratama Syariah & $-0,0073$ & 0,005 & 0,4615 & $-0,0063$ & Negatif \\
\hline $\begin{array}{l}\text { Bahana Icon } \\
\text { Syariah }\end{array}$ & $-0,0044$ & 0,005 & 0,6125 & $-0,0014$ & Negatif \\
\hline $\begin{array}{l}\text { Pacific Saham } \\
\text { Syariah }\end{array}$ & 0,0078 & 0,005 & 0,3375 & 0,0072 & Positif \\
\hline $\begin{array}{l}\text { Maybank Syariah } \\
\text { Equity Fund }\end{array}$ & $-0,0117$ & 0,005 & 0,3615 & $-0,0120$ & Negatif \\
\hline $\begin{array}{l}\text { BNI-AM Dana } \\
\text { Saham Syariah } \\
\text { Musahamah }\end{array}$ & $-0,0092$ & 0,005 & 0,5880 & $-0,0067$ & Negatif \\
\hline
\end{tabular}




\begin{tabular}{|l|l|l|l|l|l|}
\hline $\begin{array}{l}\text { KAM Kapital } \\
\text { Syariah }\end{array}$ & $-\mathbf{0 , 0 1 0 3}$ & $\mathbf{0 , 0 0 5}$ & $\mathbf{0 , 0 0 6 8}$ & $\mathbf{- 0 , 0 1 5 2}$ & Negatif \\
\hline
\end{tabular}

Sumber: OJK tahun 2018, data diolah peneliti

\subsubsection{Hasil Perhitungan Kinerja Pasar (JII) sebagai Benchmark}

Perhitungan ini dilakukan untuk mengetahui tolok ukur/benchmark (JII) yang nantinya sebagai pembanding dari kinerja reksadana saham syariah apakah mampu outperform (melebihi pasar) atau underperform (dibawah pasar). Perhitungan kinerja benchmark (JII) pada periode 2017 dan 2018 menggunakan rumus yang sama sebagaimana dengan perhitungan return bulanan pasar. Akan tetapi perhitungan kinerja ini dilakukan menggunakan data nilai JII bulan akhir periode suatu tahun tertentu dan data nilai JII bulan awal tahun yang bersangkutan.

Hasil perhitungan menunjukkan bahwa return/kinerja pasar (JII) sebagai benchmark periode 2017 yaitu sebesar 0,0992 dari return/kinerja pasar (JII) sebagai benchmark periode 2018 yaitu sebesar -0,1295. Hasil tersebut nantinya akan digunakan sebagai tolok ukur (benchmark) atau pembanding terhadap kinerja reksadana saham syariah dalam penelitian ini, dan nantinya akan diketahui kinerja reksadana saham syariah mana saja yang mampu outperform (melebihi pasar) atau underperform (dibawah pasar).

Suatu reksadana saham syariah dikatakan mampu memiliki status outperform (baik) apabila memiliki kinerja di atas kinerja suatu pasar (benchmark) dan begitu juga sebaliknya suatu reksadana saham syariah dikatakan memiliki status underperform (kurang baik) apabila memiliki kinerja di bawah kinerja suatu pasar. Jadi, lebih baik berinvestasi di reksadana saham syariah yang mampu memiliki kinerja outperform terhadap pasar daripada underperform terhadap pasar karena dengan berstatus outperform suatu reksadana saham syariah tersebut berarti memiliki kinerja yang baik dan mampu memiliki return yang tinggi dan dengan tingkat risiko yang rendah.

\subsection{Pembahasan}

3.2.1 Kinerja Reksadana Saham Syariah dengan Metode Sharpe serta Perbandingannya terhadap Benchmark (JII)

a. Kinerja Reksadana Saham Syariah dengan Metode Sharpe serta Perbandingannya terhadap Benchmark (JII) pada Periode 2017

Dari hasil analisis yang telah dilakukan dengan metode sharpe dapat diketahui terdapat beberapa reksadana saham syariah yang memiliki kinerja positif dan ada juga yang berkinerja negatif. Berikut tabel ulasan hasil kinerja reksadana saham syariah dengan metode sharpe pada periode 2017.

Tabel. 3.7. Ulasan Hasil Kinerja Reksadana Saham Syariah dengan Metode Sharpe Periode 2017

\begin{tabular}{|c|c|}
\hline Kinerja Positif & Kinerja Negatif \\
\hline 7 Reksadana Saham Syariah & 16 Reksadana Saham Syariah \\
\hline
\end{tabular}

Sumber : Tabel 3.1

Berdasarkan tabel 3.7. dapat diketahui bahwa kinerja reksadana saham syariah periode 2017 dengan metode sharpe, terdapat 7 reksadana saham syariah memiliki kinerja positif dan 16 reksadana saham syariah yang memiliki kinerja 
negatif. Berdasarkan data tersebut, hal ini menunjukan bahwa terdapat 7 reksadana saham syariah yang layak dipertimbangkan bagi investor untuk berinvestasi pada periode 2017 berdasarkan metode tersebut karena memiliki kinerja positif dan pastinya mampu memberikan return yang maksimal dengan tingkat risiko yang rendah.

Setelah mengetahui besarnya kinerja reksadana saham syariah berdasarkan metode sharpe pada periode 2017, langkah berikutnya yaitu membandingkan kinerja reksadana saham syariah tersebut dengan kinerja benchmark (JII) untuk lebih memantapkan lagi dari ketujuh reksadana saham syariah yang berkinerja positif manakah yang mampu outperform terhadap kinerja pasar pada periode 2017, Seperti diketahui hasil benchmark tahun 2017 sebesar 0,0992. Maka perusahaan yang masuk outperform berjumlah 5 yaitu Sucorinvest Sharia Equity Fund 0,4275, KAM Kapital Syariah 0,2526, TRIM Syariah Saham 0,1418, Pacific Saham Syariah 0,1418 dan MNC Dana Syariah Ekuitas 0,1279. Sedang yang lainnya underperform. Hal ini menunjukan bahwa terdapat 5 reksadana saham syariah pada periode 2017 yang layak untuk dipertimbangkan oleh investor sebagai tempat berinvestasi, karena selain berkinerja positif reksadana saham syariah tersebut juga mampu outperform terhadap pasar. Sehingga mampu memberikan return yang maksimal dan juga memiliki tingkat risiko yang rendah.

\section{b. Kinerja Reksadana Saham Syariah dengan Metode Sharpe serta Perbandingannya terhadap Benchmark (JII) pada Periode 2018}

Dari hasil analisis yang telah dilakukan dengan metode sharpe dapat diketahui terdapat beberapa reksadana saham syariah yang memiliki kinerja positif dan ada juga yang berkinerja negatif.

Tabel. 3.8.Ulasan Hasil Kinerja Reksadana Saham Syariah dengan Metode Sharpe Periode 2018

\begin{tabular}{|c|c|}
\hline Kinerja Positif & Kinerja Negatif \\
\hline 3 Reksadana Saham Syariah & 20 Reksadana Saham Syariah \\
\hline
\end{tabular}

Sumber : Tabel 3.2

Berdasarkan tabel tersebut dapat diketahui bahwa kinerja reksadana saham syariah periode 2018 dengan metode sharpe, diperoleh hasil bahwa terdapat 3 reksadana saham syariah memiliki kinerja positif. Dan 20 reksadana saham syariah yang memiliki kinerja negatif. Hal ini menunjukan bahwa terdapat 3 reksadana saham syariah yang layak dipertimbangkan bagi investor untuk berinvestasi pada periode 2018 berdasarkan metode tersebut karena memiliki kinerja positif dan pastinya mampu memberikan return yang maksimal dengan tingkat risiko yang rendah.

Setelah mengetahui besarnya kinerja reksadana saham syariah berdasarkan metode sharpe pada periode 2018, langkah berikutnya yaitu membandingkan kinerja reksadana saham syariah tersebut dengan kinerja benchmark (JII) untuk lebih memantapkan lagi dari ketujuh reksadana saham syariah yang berkinerja positif manakah yang mampu outperform terhadap kinerja pasar pada periode 2018, Seperti diketahui hasil benchmark tahun 2017 sebesar -0,1295. Maka perusahaan yang masuk outperform berjumlah 3 yaitu Simas Syariah Unggulan 0,2966, Sucorinvest Sharia Equity Fund 0,1226 dan Pacific Saham Syariah 0,0982 Outperform. Sedang yang lainnya underperform. Hal ini menunjukan bahwa terdapat 3 reksadana saham 
syariah pada periode 2018 yang layak untuk dipertimbangkan oleh investor sebagai tempat berinvestasi, karena selain berkinerja positif reksadana saham syariah tersebut juga mampu outperform terhadap pasar. Sehingga mampu memberikan return yang maksimal dan juga memiliki tingkat risiko yang rendah.

\subsubsection{Kinerja Reksadana Saham Syariah dengan Metode Treynor serta} Perbandingannya terhadap Benchmark (JII)

a. Kinerja Reksadana Saham Syariah dengan Metode Treynor serta Perbandingannya terhadap Benchmark (JII) pada Periode 2017

Dari hasil analisis yang telah dilakukan dengan metode treynor dapat diketahui terdapat beberapa reksadana saham syariah yang memiliki kinerja positif dan ada juga yang berkinerja negatif.

Tabel.3.9. Ulasan Hasil Kinerja Reksadana Saham Syariah dengan Metode Treynor Periode 2017

\begin{tabular}{|c|c|}
\hline Kinerja Positif & Kinerja Negatif \\
\hline 7 Reksadana Saham Syariah & 16 Reksadana Saham Syariah \\
\hline
\end{tabular}

Sumber : Tabel 3.3.

Berdasarkan tabel tersebut dapat diketahui bahwa kinerja reksadana saham syariah periode 2017 dengan metode treynor, diperoleh hasil bahwa terdapat 7 reksadana saham syariah memiliki kinerja positif. Dan 16 reksadana saham syariah yang memiliki kinerja negatif. Hal ini menunjukan bahwa terdapat 7 reksadana saham syariah yang layak dipertimbangkan bagi investor untuk berinvestasi pada periode 2017 berdasarkan metode tersebut karena memiliki kinerja positif dan pastinya mampu memberikan return yang maksimal dengan tingkat risiko yang rendah.

Setelah mengetahui besarnya kinerja reksadana saham syariah berdasarkan metode treynor pada periode 2017, langkah berikutnya yaitu membandingkan kinerja reksadana saham syariah tersebut dengan kinerja benchmark (JII) untuk lebih memantapkan lagi dari ketujuh reksadana saham syariah yang berkinerja positif manakah yang mampu outperform terhadap kinerja pasar pada periode 2017. Dari hasil perhitungan benchmark diperoleh hasil 0,0992 sehingan hanya satu perusahaan yang masuk outperform yaitu KAM Kapital Syariah 0,1201 sedang 22 perusahaan lainnya underperform.

b. Kinerja Reksadana Saham Syariah dengan Metode Treynor serta Perbandingannya terhadap Benchmark (JII) pada Periode 2018

Dari hasil analisis yang telah dilakukan dengan metode treynor dapat diketahui terdapat beberapa reksadana saham syariah yang memiliki kinerja positif dan ada juga yang berkinerja negatif.

Tabel 4.0. Ulasan Hasil Kinerja Reksadana Saham Syariah dengan Metode Treynor Periode 2018

\begin{tabular}{|c|c|}
\hline Kinerja Positif & Kinerja Negatif \\
\hline 3 Reksadana Saham Syariah & 20 Reksadana Saham Syariah \\
\hline
\end{tabular}

Sumber : Tabel 3.4 . 
Berdasarkan tabel tersebut dapat diketahui bahwa kinerja reksadana saham syariah periode 2018 dengan metode treynor, diperoleh hasil bahwa terdapat 3 reksadana saham syariah memiliki kinerja positif. Dan 20 reksadana saham syariah yang memiliki kinerja negatif. Hal ini menunjukan bahwa terdapat 3 reksadana saham syariah yang layak dipertimbangkan bagi investor untuk berinvestasi pada periode 2018 berdasarkan metode tersebut karena memiliki kinerja positif dan pastinya mampu memberikan return yang maksimal dengan tingkat risiko yang rendah.

Setelah mengetahui besarnya kinerja reksadana saham syariah berdasarkan metode treynor pada periode 2018, langkah berikutnya yaitu membandingkan kinerja reksadana saham syariah tersebut dengan kinerja benchmark (JII) untuk lebih memantapkan lagi dari ketujuh reksadana saham syariah yang berkinerja positif manakah yang mampu outperform terhadap kinerja pasar pada periode 2018. Dari hasil perhitungan benchmark diperoleh hasil $-0,1295$ sehingga hanya 3 perusahaan yang masuk underform yaitu, OSO Syariah Equity Fund -0,1362, HPAM Syariah Ekuitas -0,3504 dan KAM Kapital Syariah -2,25, sedang 20 perusahaan lainnya outperform.

\subsubsection{Kinerja Reksadana Saham Syariah dengan Metode Jensen serta Perbandingannya terhadap Benchmark (JII)}

a. Kinerja Reksadana Saham Syariah dengan Metode Jensen serta Perbandingannya terhadap Benchmark (JII) pada Periode 2017

Dari hasil analisis yang telah dilakukan dengan metode jensen dapat diketahui terdapat beberapa reksadana saham syariah yang memiliki kinerja positif dan ada juga yang berkinerja negatif.

Tabel 4.1. Ulasan Hasil Kinerja Reksadana Saham Syariah dengan Metode Jensen Periode 2017

\begin{tabular}{|c|c|}
\hline Kinerja Positif & Kinerja Negatif \\
\hline 6 Reksadana Saham Syariah & 17 Reksadana Saham Syariah \\
\hline
\end{tabular}

Berdasarkan tabel tersebut dapat diketahui bahwa kinerja reksadana saham syariah periode 2017 dengan metode jensen, diperoleh hasil bahwa terdapat 6 reksadana saham syariah memiliki kinerja positif dan 17 reksadana saham syariah yang memiliki kinerja negatif. Hal ini menunjukan bahwa terdapat 6 reksadana saham syariah yang layak dipertimbangkan bagi investor untuk berinvestasi pada periode 2017 berdasarkan metode tersebut karena memiliki kinerja positif dan pastinya mampu memberikan return yang maksimal dengan tingkat risiko yang rendah.

Setelah mengetahui besarnya kinerja reksadana saham syariah berdasarkan metode jensen pada periode 2017, langkah berikutnya yaitu membandingkan kinerja reksadana saham syariah tersebut dengan kinerja benchmark (JII) untuk lebih memantapkan lagi dari ketujuh reksadana saham syariah yang berkinerja positif manakah yang mampu outperform terhadap kinerja pasar pada periode 2018. Dari hasil perhitungan benchmark diperoleh hasil 0,0992 sehingga tidak ada satu pun perusahaan yang masuk ourperform, ke 23 masuk underform.

\section{b. Kinerja Reksadana Saham Syariah dengan Metode Jensen serta Perbandingannya terhadap Benchmark (JII) pada Periode 2018}


Dari hasil analisis yang telah dilakukan dengan metode jensen dapat diketahui terdapat beberapa reksadana saham syariah yang memiliki kinerja positif dan ada juga yang berkinerja negatif.

Tabel 4.1. Ulasan Hasil Kinerja Reksadana Saham Syariah dengan Metode Jensen Periode 2018

\begin{tabular}{|c|c|}
\hline Kinerja Positif & Kinerja Negatif \\
\hline 5 Reksadana Saham Syariah & 18 Reksadana Saham Syariah \\
\hline
\end{tabular}

Berdasarkan tabel tersebut dapat diketahui bahwa kinerja reksadana saham syariah periode 2018 dengan metode jensen, diperoleh hasil bahwa terdapat 5 reksadana saham syariah memiliki kinerja positif. Dan 18 reksadana saham syariah yang memiliki kinerja negatif. Hal ini menunjukan bahwa terdapat 5 reksadana saham syariah yang layak dipertimbangkan bagi investor untuk berinvestasi pada periode 2018 berdasarkan metode tersebut karena memiliki kinerja positif dan pastinya mampu memberikan return yang maksimal dengan tingkat risiko yang rendah.

Setelah mengetahui besarnya kinerja reksadana saham syariah berdasarkan metode treynor pada periode 2018, langkah berikutnya yaitu membandingkan kinerja reksadana saham syariah tersebut dengan kinerja benchmark (JII) untuk lebih memantapkan lagi dari ketujuh reksadana saham syariah yang berkinerja positif manakah yang mampu outperform terhadap kinerja pasar pada periode 2018. Dari hasil perhitungan benchmark diperoleh hasil -0,1295 sehingga seluruh perusahaan outperform.

\section{PENUTUP (SIMPULAN)}

Penelitian ini bertujuan untuk mengetahui kinerja reksadana saham syariah berdasarkan metode sharpe, treynor dan jensen dengan kinerja benchmark (JII) pada periode 2017- 2018. Data yang diperoleh kemudian diolah dan dianalisis secara deskriptif komparatif dengan pendekatan kuantitatif. Berdasarkan hasil analisis yang telah dilakukan, maka dapat diambil kesimpulan sebagai berikut:

1.Kinerja Reksadana Saham Syariah dengan Metode Sharpe, Treynor dan Jensen Periode 2017 dan 2018

Menurut metode sharpe pada periode 2017 dari 23 reksadana saham syariah terdapat 7 reksadana yang menunjukkan kinerja positif, sedangkan pada periode 2018 terdapat 3 reksadana saham syariah menunjukkan kinerja positif. reksadana dengan hasil yang positif menunjukkan bahwa return yang dihasilkan melebihi risikonya (standar deviasi). Berdasarkan perhitungan kinerja reksadana saham syariah yang diukur dengan metode sharpe pada periode 2017 kinerja terbaik diraih oleh reksadana Sucorinvest Sharia Equity Fund dengan nilai sharpe sebesar $(0,4275)$. Sedangkan pada periode 2018 kinerja terbaik diraih oleh reksadana Simas Syariah Unggulan dengan nilai sharpe sebesar $(0,2966)$. Semakin tinggi nilai sharpe suatu reksadana saham syariah, maka kinerjanya semakin baik. 
Menurut metode treynor pada periode 2017 terdapat 7 reksadana saham syariah yang menunjukkan kinerja positif, sedangkan pada periode 2018 terdapat 3 reksadana saham syariah yang menunjukkan kinerja positif. Semakin tinggi nilai treynor yang dihasilkan maka semakin tinggi kemampuan reksadana menanggulangi risiko yang mungkin akan terjadi. Berdasarkan perhitungan kinerja reksadana saham syariah yang diukur dengan metode treynor pada periode 2017 kinerja terbaik diraih oleh reksadana KAM Kapital Syariah dengan nilai treynor sebesar (0,1201). Sedangkan pada periode 2018 kinerja terbaik diraih oleh reksadana Simas Syariah Unggulan dengan nilai treynor sebesar $(0,1694)$.

Menurut metode jensen pada periode 2017 terdapat 6 reksadana saham syariah yang menunjukkan kinerja positif. Sedangkan pada periode 2018 terdapat 5 reksadana saham syariah yang menunjukkan kinerja positif. Reksadana saham syariah yang memiliki nilai jensen positif berarti memiliki kinerja lebih baik dari pasar (superior terhadap pasar), dengan kata lain reksadana saham syariah yang superior adalah reksadana saham syariah yang outperform. Berdasarkan perhitungan kinerja reksadana saham syariah yang diukur dengan metode jensen pada periode 2017 kinerja terbaik diraih oleh reksadana KAM Kapital Syariah dengan nilai jensen sebesar (0,021). Sedangkan pada periode 2018 kinerja terbaik diraih oleh Simas Syariah Unggulan dengan nilai jensen sebesar $(0,0226)$. Semakin tinggi nilai jensen dari suatu reksadana saham syariah maka kinerjanya semakin baik.

2. Reksadana Saham Syariah yang Memiliki Kinerja Outperform dan Underperform terhadap Kinerja Benchmark selama Periode 2017-2018

Menurut metode sharpe pada tahun 2017 terdapat 5 reksadana saham syariah yang memiliki kinerja outperform dan 18 reksadana saham syariah berkinerja underperform, sedangkan pada tahun 2018 terdapat 3 reksadana saham syariah yang memiliki outperform dan 20 reksadana saham syariah yang berkinerja underperform.

Berdasarkan metode treynor, terdapat 1 reksadana saham syariah yang memiliki kinerja outperform dan 22 reksadana saham syariah yang berkinerja underperform pada periode 2017 dan sebanyak 20 reksadana saham syariah yang memiliki kinerja outperform dan 3 reksadana saham syariah yang berkinerja underperform pada periode 2018.

Sedangkan menurut metode jensen, tidak terdapat reksadana saham syariah yang memiliki kinerja outperform dan 23 reksadana saham syariah yang berkinerja underperform pada periode 2017 dan sebanyak 23 reksadana saham syariah yang memiliki kinerja outperform dan tidak terdapat reksadana saham syariah yang berkinerja underperform pada periode 2018.

Berdasarkan urutan peringkat empat besar reksadana saham syariah yang memiliki kinerja terbaik pada setiap metode dan periode penelitian, terdapat 2 reksadana saham syariah yang paling konsisten memiliki kinerja terbaik terhadap kinerja pasar pada semua metode selama periode 2017-2018 yaitu reksadana saham syariah Sucorinvest Sharia Equity Fund dari Manajer Investasi PT. Sucorinvest Asset Management dan Pacific Saham Syariah dari Manajer Investasi PT. Pacific Capital Investment. 


\section{DAFTAR PUSTAKA}

Al Quran Surah Al-Hasyr Ayat 18 (2011), Alquran dan Terjemahnya. CV Penerbit Diponegoro, Bandung.

Al Quran Surah Al-Luqman Ayat 34 (2011), Alquran dan Terjemahnya. CV Penerbit Diponegoro, Bandung.

Fatwa DSN-MUI, Nomor 20/DSN MUI/IV/2001, Reksadana Syariah, 18 April 2001.

Fatwa DSN-MUI, Nomor 20/DSN MUI/IV/2001, Mekanisme Operasional Reksadana syariah, 18 April 2001.

Hadi, Nor (2013). Pasar Modal Acuan Teoritis dan Praktis Investasi di Instrumen Keuangan Pasar Modal. Graha Ilmu, Yogyakarta

Hadi, Nor (2015). Pasar Modal Edisi 2. Graha Ilmu, Yogyakarta.

Halim, Abdul (2015). Analisis Investasi Edisi 2. Salemba Empat, Jakarta.

Hartono, Jogiyanto (2010). Teori Portofolio dan Analisis Investasi edisi ketujuh. BPFEUGM, Yogyakarta

Hartono, Jogiyanto (2014). Teori Portofolio dan Analisis Investasi Edisi 9. BPFEYogyakarta.

Haymans Manurung, Adler (2008). Reksadana Investasiku. Kompas, Jakarta.

Huda, Nurul, dan Mohamad Heykal (2010), Lembaga Keuangan Islam Tinjauan Teoritis dan Praktis. Kencana Prenada Media Group, Jakarta.

Husnan, Suad (2001). Dasar-Dasar Teori Portofolio dan Analisis Sekuritas Edisi 3. Unit Penerbit dan Percetakan AMP YKPN, Yogyakarta.

Iman, Nofie (2008). Panduan Singkat dan Praktis Memulai Investasi Reksadana. PT Elex Media Komputindo, Jakarta.

J. Fabozzi, Frank (2000). Manajemen Investasi. Salemba Empat, Jakarta.

Manurung, A (2006). Ke mana Investasi? Kiat dan Panduan Investasi keuangan di Indonesia. PT Kompas Media Nusantara, Jakarta.

Priyo Pratomo, Eko (2009). Reksa Dana Solusi Perencanaan Investasi di Era Modern. Gramedia Pustaka Utama, Jakarta.

Purwanto, Suharyadi (2008). Statistika untuk Ekonomi dan Keuangan Modern. Salemba Empat, Jakarta.

Rahardjo, Sapto. Panduan Investasi Reksadana. PT Elex Media Komputindo, Jakarta. 
Situmorang, Parluhutan, dkk (2010)., Langkah Awal Berinvestasi Reksadana. Trans media Pustaka, Jakarta.

Sugiyono (2014), Metode Penelitian Bisnis Pendekatan Kuantitaif, Kualitatif dan R\&D. Alfabeta, Bandung.

Sukardi Kodrat, David, dan Kurniawan Indonanjaya (2010). Manajemen Investasi Pendekatan Teknikal dan Fundamental untuk Analisis Saham. Graha Ilmu, Yogyakarta.

Sutedi, Adrian (2011). Pasar Modal Syariah Sarana Investasi Keuangan Berdasarkan Prinsip Syariah. Sinar Grafika, Jakarta.

Syaodih Sukmadinata, Nana (2010). Metode Penelitian Pendidikan. Remaja Rosdakarya, Bandung.

Tan, Inggrid (2013). Bisnis dan Investasi Sistem Syariah. Universitas Atma Jaya, Yogyakarta.

Tandelilin, Enduardus (2001). Analisis Investasi dan Manajemen Portofolio. BPFE, Yogyakarta.

Tandelilin, Enduardus (2010). Portofolio dan Investasi Teori dan Aplikasi. Kanisius, Yogyakarta.

Tri Handayani, Diah, dan Saparila Worokinasih (2018). "Analisis Kinerja Investasi Reksadana Syariah di Indonesia dengan Metode Sharpe, Treynor dan Jensen" Jurnal Administrasi Bisnis (JAB) Vol. 59, No. 1, 2018.

Trisna Wardhani, Raudhah, Ahmad Juanda, dan Dhaniel Syam (2018). "Analisis Kinerja Reksadana Syariah di Pasar Modal Indonesia Menggunakan Metode Sharpe," Jurnal Akademi Akuntansi Volume. 1 No. 1, 2018.

Wahyu Anggara, Aldias, dan Arief Yulianto (2017). "Analisis Kinerja Reksa Dana Saham dengan Metode Sharpe, Treynor dan Jensen," Management Analysis Journal (MAJ) Vol. 6, No. 1, 2017.

Yuliana, Indah. Investasi Produk Keuangan Syariah. Malang: UIN Maliki Press, 2010.

"Jakarta Islamic Index (JII)", 23 juli, 2019, https://www.idx.co.id/id syariah/indekssaham-syariah/

"Struktur Organisasi Pelaku Pasar Modal", diakses pada 19 Agustus, 2019, https://www.finansialku.com/struktur-organisasi-pelaku-pasarmodal/amp/.

19/P0JK.04/2015, Penerbitan dan Persyaratan Reksadana Syariah, 3 November 2015. 